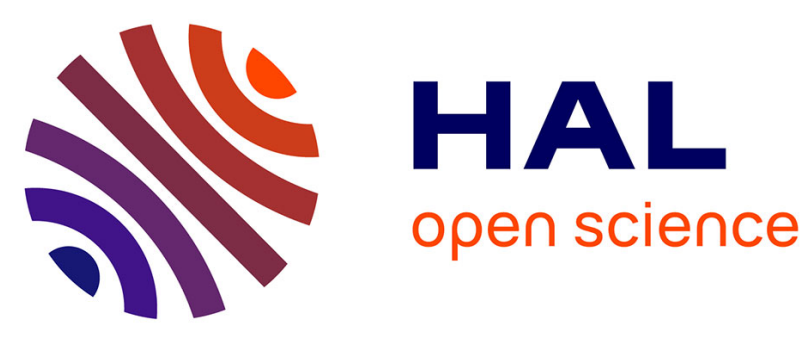

\title{
Design, synthesis and anticancer properties of 5 -arylbenzoxepins as conformationally restricted iso combretastatin A-4 analogs
}

Evelia Rasolofonjatovo, Jérome Bignon, Olivier Provot, Abdallah Hamze, Jordi Rodrigo, Jérôme Bignon, Joanna Wdzieczak-Bakala, Christine Lenoir, Déborah Desravines, Joëlle Dubois, et al.

\section{To cite this version:}

Evelia Rasolofonjatovo, Jérome Bignon, Olivier Provot, Abdallah Hamze, Jordi Rodrigo, et al.. Design, synthesis and anticancer properties of 5-arylbenzoxepins as conformationally restricted iso combretastatin A-4 analogs. European Journal of Medicinal Chemistry, 2013, 62, pp.28-39. 10.1016/j.ejmech.2012.12.042 . hal-02394390

\section{HAL Id: hal-02394390 \\ https://hal.science/hal-02394390}

Submitted on 4 Dec 2019

HAL is a multi-disciplinary open access archive for the deposit and dissemination of scientific research documents, whether they are published or not. The documents may come from teaching and research institutions in France or abroad, or from public or private research centers.
L'archive ouverte pluridisciplinaire HAL, est destinée au dépôt et à la diffusion de documents scientifiques de niveau recherche, publiés ou non, émanant des établissements d'enseignement et de recherche français ou étrangers, des laboratoires publics ou privés. 


\title{
Design, synthesis and anticancer properties of 5- arylbenzoxepins as conformationally restricted isoCombretastatin A-4 analogues
}

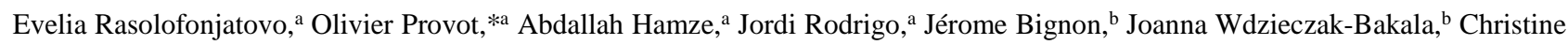
Lenoir, ${ }^{\mathrm{b}}$ Déborah Desravines, ${ }^{\mathrm{b}}$ Joëlle Dubois, ${ }^{\mathrm{b}}$ Jean-Daniel Brion, ${ }^{\mathrm{a}}$ Mouad Alami*a

${ }^{a}$ Univ. Paris-Sud, CNRS, BioCIS-UMR 8076, LabEx LERMIT, Laboratoire de Chimie Thérapeutique, Faculté de Pharmacie, 5 rue J.-B. Clément, Châtenay-Malabry, F-92296, France.

${ }^{b}$ Institut de Chimie des Substances Naturelles, UPR 2301, CNRS avenue de la terrasse, F-91198 Gif sur Yvette, France.

* Corresponding authors. Tel.: +33 14683588 47. Fax: +33 1468358 28. Email: olivier.provot@u-psud.fr (O.P.) or mouad.alami@u-psud.fr (M.A.).

\begin{abstract}
A series of novel benzoxepins 6 was designed and prepared as rigid-isoCA-4 analogues according to a convergent strategy using the coupling of $N$-tosylhydrazones with aryl iodides under palladium catalysis. The most potent compound $\mathbf{6 b}$, having the greatest resemblance to CA-4 and isoCA-4 displayed antiproliferative activity at nanomolar concentrations against various cancer cell lines and inhibited tubulin assembly at a micromolar range. In addition, benzoxepin $\mathbf{6 b}$ led to the arrest of HCT116, K562, H1299 and MDA-MB231 cancer cell lines in the $\mathrm{G}_{2} / \mathrm{M}$ phase of the cell cycle, and strongly induced apoptosis at low concentrations. Docking studies demonstrated that benzoxepin $\mathbf{6 b}$ adopt an orientation similar to that of isoCA-4 at the colchicine binding site on $\beta$-tubulin.
\end{abstract}

Keywords: Benzoxepin, Combretastatin, isoCA-4, Tubulin, Cytotoxicity, Apoptosis, Cancer 


\section{Introduction}

Combretastatin A-4 (CA-4, Figure 1), a natural stilbene isolated by Pettit[1] from the South African tree Combretum caffrum, is potently cytotoxic against a variety of cancer cells, including multidrug-resistant cell lines.[2,3] CA-4, which binds on $\beta$-tubulin at the colchicine binding site, is also an exceptionally strong inhibitor of tubulin polymerization with an IC 50 value of $1.0 \mu \mathrm{M}$.[4] Disruption of tubulin assembly results in rapid tumor endothelial cell damage followed by neovascular shutdown, and subsequent hemorrhagic necrosis.[5] A great interest in CA-4 is reflected in the fact that the water soluble phosphate prodrug CA-4P (fosbretabulin, 1b)[6,7] is currently used for advanced anaplastic thyroid carcinoma, even if some vascular side effects were reported.[8,9] Despite its remarkable anticancer activity, CA-4 isomerizes into its inactive (E)-isomer[10] during storage, administration[11] and metabolism[12] leading to a significant loss of potency. The poor bioavailability and solubility in biological media associated with the $Z$ to $E$-isomerization drawback,[11] together with the structural simplicity of CA-4, makes it very interesting from a medicinal chemistry point of view, thus stimulating the search for new and more potent compounds with improved pharmacological properties[13,14] Considerable effort has been gone into modifying the isomerizable cis carbon-carbon double bond. Several reviews outlined this vast array of chemistry focusing on the stabilization of the two aryl rings of CA-4 using one to three atom bridgeheads.[15-20]

\section{<Figure 1>}

Figure 1. Representative inhibitors of tubulin polymerization and rational drug design from CA-4 and isoCA-4 to dihydrobenzoxepin analogues 6.

In our efforts to discover novel CA-4 analogues having non-isomerizable linkers between the A- and B-rings,[21-26], we recently synthesized a series of 1,1-diarylethylene derivatives[27-29] with general structure 2 . The most active molecules in this series, isoCA4 (2a), iso $\mathrm{NH}_{2} \mathrm{CA}-4$ (2b), isoFCA-4 (2c) and 2d displayed a nanomolar level of cytotoxicity against various cancer cell lines, inhibited tubulin polymerization (ITP) at a micromolar level, and arrested cancer cells in the $\mathrm{G}_{2} / \mathrm{M}$ phase of the cell cycle (Figure 1).[30-33] These 1,1-diarylethylene compounds 2 were found to be as active as their $(Z)$-1,2-ethylene isomers $\left(\mathrm{CA}^{-4} \mathbf{1 a}, \mathrm{NH}_{2} \mathrm{CA}-4\right.$ 1c, FCA-4 1d), clearly demonstrating that it is possible to replace the (Z)-double bond of CA-4 derivatives with a 1,1-ethylene unit with no loss of efficacy.

IsoCA-4 was utilized as a starting point to design cyclic and heterocyclic derivatives 3-5 with restricted rotation to identify novel compounds with improved anticancer activities. Inserting the double bond of isoCA-4 into 6-membered rings led to (dihydro)naphtalene 3[34-36] and chromene 4[37,38] derivatives endowed with interesting anticancer activities (Figure 1). In 2008, Pinney reported the synthesis of benzosuberenes of type 5[39,40] as highly cytotoxic agents, demonstrating that the double bond in isoCA-4 could be successfully included in a 7-membered ring to maintain potent activity against various cancer cell lines. In continuation of our earlier work, a novel series of restricted isoCA-4 derivatives 6 containing a 2,3-dihydrobenzoxepin ring was designed. Herein we report the synthesis, the biological evaluation and the possible binding mode of 5 -aryldihydrobenzo[b]oxepins 6.

\section{Results and discussion}

\subsection{Chemistry.}

The retrosynthetic analysis of the target 5-arylbenzoxepins $\mathbf{6}$ is outlined in Figure 2. We envisionned that the 5-aryl moiety in $\mathbf{6}$ could be installed through palladium catalyzed coupling reactions starting from (i) vinylstannanes 7 (Stille coupling, path $a$ ), (ii) vinyl iodides 8 (Suzuki coupling, path $a$ ), or (iii) $N$-tosylhydrazones 11 (path $b$ ) using a recent methodology developed by Barluenga and us[41,42] (Figure 2). To build up the 7-membered heterocyclic ring of compounds $\mathbf{7}$ and $\mathbf{8}$, a ring-closing metathesis (RCM) reaction was planned as the key step from the corresponding diene derivatives $\mathbf{9 , 1 0}$ and $\mathbf{1 3}$, respectively. An alternative route to $\mathbf{1 1}$ could be an intramolecular Mitsunobu reaction starting from phenol 12. 
Figure 2. Retrosynthetic analysis of 5-aryldihydrobenzo[b]oxepins 6.

At the outset of this work, and according to path $a$ (Scheme 1), we first studied the synthesis of diene 9a $\left(\mathrm{R}^{1}=\mathrm{R}^{2}=\mathrm{H}\right)$ through regioselective addition of $\mathrm{Bu}_{3} \mathrm{SnH}$ on the alkyne triple bond[43] of terminal arylalkyne 14.[44] As expected, we were pleased to observe a total regioselectivity in the palladium-catalyzed hydrostannylation of $\mathbf{1 4}$ leading exclusively to $\alpha$-vinylstannane $\mathbf{9 a}$ in a $80 \%$ yield. Iododestannylation of $9 \mathbf{a}$ with molecular iodine in $\mathrm{CH}_{2} \mathrm{Cl}_{2}$ at room temperature afforded $10 a\left(\mathrm{R}^{1}=\mathrm{R}^{2}=\mathrm{H}\right)$ in a modest and non-optimized yield of $45 \%$. Unfortunately, despite attempting a plethora of RCM conditions using the Grubbs I, Grubbs II, and Hoveyda-Grubbs catalysts (from $2 \%$ to $20 \%$ ) in $\mathrm{CH}_{2} \mathrm{Cl}_{2}$, toluene at different temperatures (from $20{ }^{\circ} \mathrm{C}$ to reflux) and various concentrations, no macrocyclization of dienes $9 \mathbf{a}$ and $\mathbf{1 0 a}$ was ever observed.

\section{$<$ Scheme 1>}

Scheme 1. Synthesis of vinylstannane 9a and vinyliodide 10a. Reagent and conditions: a) $\mathrm{PdCl}_{2}\left(\mathrm{PPh}_{3}\right)_{2}(2 \mathrm{~mol}), \mathrm{Bu}_{3} \mathrm{SnH}(1.2$ equiv), THF, $20^{\circ} \mathrm{C}$; b) $\mathrm{I}_{2}, \mathrm{CH}_{2} \mathrm{Cl}_{2}, 20^{\circ} \mathrm{C}$.

The synthesis of benzoxepin derivatives 6 was next envisioned according to path $b$ involving an intramolecular Mitsunobu reaction (Scheme 2). Initially, the compounds targeted $\mathbf{6 b}$ and $\mathbf{6 c}$ contain on the benzoxepin nucleus 9-hydroxy and 8-methoxy substituents which are present in the isoCA-4 B-ring, and that were proved to be essential for bioactivity (Scheme 2).

\section{<Scheme 2>}

Scheme 2. Synthesis of dihydrobenzoxepins 6b,c. Reagent and conditions: a) $\mathrm{MOMCl}$ (2 equiv), $i \operatorname{Pr}_{2} \mathrm{NH}\left(2\right.$ equiv), $\mathrm{CH}_{2} \mathrm{Cl}_{2}$; b) $\mathrm{But}_{-}$ 3-yn-1-ol (1.1 equiv), $\mathrm{PdCl}_{2}\left(\mathrm{PPh}_{3}\right)_{2}$ (8 mol\%), $\mathrm{CuI}(15 \mathrm{~mol} \%)$, Et $3 \mathrm{~N}$; c) PTSA (1 equiv), $\mathrm{H}_{2} \mathrm{O}, 100{ }^{\circ} \mathrm{C}$, sealed tube; d) DEAD (1.5 equiv), $\mathrm{PPh}_{3}$ (1.5 equiv), THF; e) $\mathrm{TsNHNH}_{2}$ (2.5 equiv), PTSA (20 mol\%), EtOH reflux; f) $\mathrm{Pd}_{2} \mathrm{dba}_{3}(10 \mathrm{~mol} \%), \mathrm{XPhos}(20 \mathrm{~mol} \%)$, $t \mathrm{BuOLi}$ (2 equiv), ArI (1 equiv), $90{ }^{\circ} \mathrm{C}$, sealed tube; g) $\mathrm{AlCl}_{3}$ (5 equiv), $\mathrm{CH}_{2} \mathrm{Cl}_{2}$.

Arylalkynol 17[45] was prepared from iodophenol 15 through a sequence of MOM-ether protection followed by a SonogashiraLinstrumelle coupling reaction[46,47] with homopropargylic alcohol. The triple bond of $\mathbf{1 7}$ was regioselectively hydrated in the presence of PTSA[48-52] in water, and a subsequent intramolecular Mitsonobu reaction furnished the required benzoxepan-5-one 19 in a $63 \%$ yield. This latter was mixed with $\mathrm{TsNHNH}_{2}$ in the presence of PTSA to afford the key intermediate $N$-tosylhydrazone 11a, which in turn was coupled with various aryl halides under $\mathrm{Pd}_{2} \mathrm{dba} / \mathrm{XPhos}$ as the catalytic system.[41,53] Accordingly, trimethoxyphenylbenzoxepin 6a was formed in an excellent 98\% yield.[54,55] Finally, the phenolic part of isopropylether 6a was revealed by treatment with $\mathrm{AlCl}_{3}$ to give $\mathbf{6 b}$ but in a low $15 \%$ yield. Target molecule $\mathbf{6 c}$, with a 3,5-dimethoxyphenyl nucleus as Aring, was also prepared from $N$-tosylhydrazone 11a, and the resulting crude coupling product treated with $\mathrm{AlCl}_{3}$ in $\mathrm{CH}_{2} \mathrm{Cl}_{2}$ furnished the desired benzoxepin derivative $\mathbf{6 c}$ in a modest $25 \%$ yield.

For benzoxepin derivatives 6d-g having different substituents on C9, we envisioned their synthesis via a convergent approach starting from $\mathrm{N}$-tosylhydrazone 11b having a bromine atom at the $\mathrm{C} 9$ position, useful for subsequent functionalizations under palladium catalysis (Scheme 3)[32,36,56]. To this end, we planned the construction of the 7-membered ring of 11b using RCM of diene 13a. Briefly, benzaldehyde 21 was prepared from isovanillin through a sequence of regioselective $N$-methylpyrrolidin-2-one hydrotribromide (MPHT) bromination[57,58] and allyl ether formation. Further reaction with vinylmagnesium chloride afforded diene 13a, which underwent ring-closing olefin metathesis using the Grubbs II catalyst in $\mathrm{CH}_{2} \mathrm{Cl}_{2}$.[59] The resulting dihydrobenzoxepin-5-ol 22 was subjected to a double bond reduction, PCC alcohol oxidation and then $N$-tosylhydrazone formation to give 11b. Further palladium-catalyzed coupling reaction with 3,4,5-trimethoxyiodobenzene furnished the key 9-bromo-8methoxybenzoxepin 6d in a $68 \%$ yield. Having achieved efficient access to $\mathbf{6 d}$, we then turned studying various means of substitution on the C9-bromo atom. The bromo substituent of $\mathbf{6 d}$ was first exploited in a coupling reaction using sodium azide as the amino source in the presence of a catalytic amount of $\mathrm{CuI}$ to give $\mathbf{6 e}(75 \%)$.[60,61] Debromination of $\mathbf{6 d}$ was achieved using catalytic amounts of $\mathrm{Pd}(\mathrm{OAc})_{2}, \mathrm{PPh}_{3}$ and $\mathrm{K}_{2} \mathrm{CO}_{3}$ in hot $n \mathrm{BuOH}$ and produced $\mathbf{6 f}$ in $69 \%$ yield.[62] For the synthesis of $\mathbf{6 g}$ having a 
butyn-1-ol chain, $6 \mathbf{d}$ was coupled with but-3-yn-1-ol using $\mathrm{PdCl}_{2}\left(\mathrm{PPh}_{3}\right)_{2}$ and $\mathrm{CuI}$ catalysts under microwave irradiation at $120{ }^{\circ} \mathrm{C}$ in DMF (74\%). Noteworthy that compound $\mathbf{6 b}$ was also prepared in an acceptable yield of 55\% by treating $\mathbf{6 d}$ with $\mathrm{KOH}$ in the presence of $\mathrm{Pd}_{2} \mathrm{dba}_{3}$ and $t \mathrm{BuXPhos}$ in a dioxane- $\mathrm{H}_{2} \mathrm{O}$ mixture according to a Buchwald protocol.[63] Finally, because the double bond present in isoCA-4 can be reduced to furnish isoerianin derivatives with no loss of anticancer properties,[23] we next focused our attention on the catalytic reduction of the carbon-carbon double bond of $\mathbf{6 b}$ and $\mathbf{6 g}$. Thus, 5-aryltetrahydrobenzoxepins 25a and 25b were obtained in non-optimized yields using $\mathrm{H}_{2}$ in the presence of $\mathrm{Pd} / \mathrm{C}$ in $\mathrm{MeOH}$ (Scheme 3).

\section{<Scheme 3>}

Scheme 3. Synthesis of dihydrobenzoxepins $\mathbf{6 b}, \mathbf{6 d - g}$ and tetrahydrobenzoxepins 25a,b. Reagent and conditions: a) $\mathrm{Hg}(\mathrm{OAc})_{2}(1$ equiv), $\mathrm{NaBr}$ ( 1 equiv), $50{ }^{\circ} \mathrm{C}$, EtOH; b) MPHT (1 equiv), $\mathrm{CH}_{3} \mathrm{CN}$; c) 3-bromoprop-1-ene (1.2 equiv), $\mathrm{K}_{2} \mathrm{CO}_{3}$ (1.2 equiv), $\mathrm{CH}_{3} \mathrm{CN}$; d) vinylmagnesium chloride (1.2 equiv), THF; e) Grubbs II catalyst, $5 \mathrm{~mol} \%, \mathrm{CH}_{2} \mathrm{Cl}_{2}, 20{ }^{\circ} \mathrm{C}$; f) $\mathrm{H}_{2}, \mathrm{Pd} / \mathrm{C}, \mathrm{MeOH}, \mathrm{AcOH}$ cat.; g) PCC, $\mathrm{CH}_{2} \mathrm{Cl}_{2}$; h) TsNHNH 2 (1 equiv), PTSA (10 mol\%), $\mathrm{MgSO}_{4}$ (1 equiv), EtOH, reflux; i) $\mathrm{Pd}_{2} \mathrm{dba}_{3}$ (10 mol\%), XPhos (40 mol\%), $t$ BuOLi (2 equiv), 3,4,5-trimethoxyiodobenzene (1.2 equiv), $90{ }^{\circ} \mathrm{C}$, sealed tube; j) $\mathrm{Pd}_{2} \mathrm{dba}_{3}(5 \mathrm{~mol} \%), t \mathrm{BuXPhos}(15 \mathrm{~mol} \%), \mathrm{KOH}(3$ equiv), dioxane- $\mathrm{H}_{2} \mathrm{O}, 90{ }^{\circ} \mathrm{C}$, sealed tube; k) $\mathrm{CuI}(10 \mathrm{~mol} \%)$, TMEDA (6 mol\%), $\mathrm{NaN}_{3}$ (2 equiv), potassium ascorbate $(6 \mathrm{~mol} \%)$ DMSO-H $\mathrm{H}_{2} \mathrm{O}, 90{ }^{\circ} \mathrm{C}$, sealed tube; 1$) \mathrm{Pd}(\mathrm{OAc})_{2}(1 \mathrm{~mol} \%), \mathrm{PPh}_{3}(2.5 \mathrm{~mol} \%), n \mathrm{BuOH}, 100{ }^{\circ} \mathrm{C}$, sealed tube; m) $n \mathrm{But}-3$-yn-1-ol (1.2 equiv), $\mathrm{PdCl}_{2}\left(\mathrm{PPh}_{3}\right)_{2}(5 \mathrm{~mol} \%), \mathrm{PPh}_{3}(15 \mathrm{~mol} \%), \mathrm{CuI}(15 \mathrm{~mol} \%), \mathrm{Et}_{2} \mathrm{NH}$ (2 equiv), DMF, $120{ }^{\circ} \mathrm{C}, \mathrm{MWI}$.

\subsection{Biological results.}

\subsubsection{In vitro cell growth assay}

All the synthesized compounds were tested in a preliminary cytotoxic assay on a human colon carcinoma (HCT116) cell line using CA-4,[64] and isoCA-4 as reference compounds.

\section{<Table 1>}

Table 1. Cytotoxic activity of dihydrobenzoxepins $6 \mathbf{b}-\mathbf{g}$ and tetrahydrobenzoxepins $25 \mathbf{a}, \mathbf{b}$ against HCT116 ${ }^{\text {[a] }}$

In this assay, the benzoxepin derivatives $\mathbf{6}$ inhibited cellular growth to a varying degree. Except tetrahydrobenzoxepin 25b, having a bulky butanol chain on C9 which was found inactive against HCT116 cells, all selected compounds displayed a nanomolar level of cytotoxicity. Lowest $\mathrm{GI}_{50}$ values were found for both bromine derivative $\left(\mathbf{6 d}, \mathrm{GI}_{50}=170 \mathrm{nM}\right)$ and compound $\mathbf{6 g}$ having a butyn-ol chain on the C9 position $(\mathbf{6 g}$, GI50 $=250 \mathrm{nM}$ ) (Table 1). These functional groups on C9 were bulky, so next we examined smaller substituents on the $\mathrm{C} 9$ position. The $\mathrm{C} 9-\mathrm{OH}$ benzoxepin derivative $\mathbf{6 b}$, having the greatest resemblance to isoCA-4 is undoubtedly the most cytotoxic compound in this series with a GI 50 value of $1.5 \mathrm{nM}$ slightly inferior to those of $i s o \mathrm{CA}-4\left(\mathrm{GI}_{50}=3 \mathrm{nM}\right)$ and CA-4 $\left(\mathrm{GI}_{50}=2 \mathrm{nM}\right)$. Contrary to Ohsumi's finding,[65] it appears that the introduction of a $\mathrm{NH}_{2}$ substituent on C9 result in weaker cytotoxicity $\left(\mathbf{6 e}, \mathrm{GI}_{50}=22 \mathrm{nM}\right)$. Compound $\mathbf{6 f}$, with no substitution on the $\mathrm{C} 9$ position showed a significative loss of activity with a $\mathrm{GI}_{50}$ value of $85 \mathrm{nM}$. Concerning the A-ring, it seems that a 3,4,5-trimethoxyphenyl ring is required for strong activity, as compound 6c $\left(\mathrm{GI}_{50}=25 \mathrm{nM}\right)$ with only two $\mathrm{MeO}$-substituents on the A-ring exhibited a lowest cytotoxicity in comparison with $6 \mathbf{b}$. Evaluation of tetrahydro-benzoxepin 25a which was found to elicit a nanomolar level of cytotoxicity (GI50 $=20 \mathrm{nM}$ ) demonstrated that the presence of the double bond in dihydrobenzoxepin compounds $\mathbf{6}$ was important but not essential for antiproliferative property as we previously showed by reducing the double bond of isoCA-4.[23]

The results reported in Table 1 showed that benzoxepins $\mathbf{6 b}$ and $6 \mathbf{6}$ having a $\mathrm{OH}$ and a $\mathrm{NH}_{2}$ substituenton $\mathrm{C} 9$ position, respectively, displayed strong cytotoxicities. Benzoxepin $\mathbf{6 b}$, having the greatest resemblance to isoCA-4 is undoubtedly the most cytotoxic compound with a $\mathrm{GI}_{50}$ value of $1.5 \mathrm{nM}$ comparable to those of $i s o \mathrm{CA}-4$ and CA-4. Compound $\mathbf{6 c}$ with only two MeO-substituents on the A-ring exhibited a decreased cytotoxicity in comparison with $6 \mathbf{b}\left(\mathrm{GI}_{50}=25 \mathrm{nM}\right)$. Contrary to previous observations in the CA4[1] and isoCA-4 series,[Erreur ! Signet non défini.] the replacement of the $\mathrm{OH}$ group by a $\mathrm{NH}_{2}$ substituent on the C9 position resulted in a slight loss of cytotoxicity as observed with compound $6 \mathbf{e}\left(\mathrm{GI}_{50}=20 \mathrm{nM}\right)$. Compound $\mathbf{6 f}$, with no substitution on the $\mathrm{C} 9$ position showed a slight loss of activity with a GI50 value of $85 \mathrm{nM}$. Contrary to our expectation,[Erreur! Signet non défini.] the 


\section{VERIFIER LES RéFéRENCES}

\subsubsection{Cytotoxicity and Inhibition of Tubulin Polymerization for Selected Compounds}

To further characterize the cytotoxicity profiles of these compounds, we investigated the effect of the more cytotoxic benzoxepins $\mathbf{6 b}, \mathbf{6 c}, \mathbf{6 e}, \mathbf{6 f}$, and $25 \mathbf{a}\left(\mathrm{GI}_{50}<85 \mathrm{nM}\right)$ on the proliferation of three human tumor cell lines: myelogenous leukemia (K562), non-small cell lung carcinoma (H1299) and hormone-independent breast cancer (MDA-MB231).

$\langle$ Table 2>

Table 2. Cytotoxic activity and inhibition of tubulin polymerization of selected compounds

The results depicted in Table 2 revealed that all selected compounds which retain a high level of cytotoxicity against HCT116 were also strongly cytotoxic with no significant disparity against K562, H1299 and MDA-MB231 cancer cell lines. Again, benzoxepin 6b was the most active compound inhibiting the growth of K562, H1299 and MDA-MB cancer cell lines with GI50 values inferior ranging from 1.5 to $8 \mathrm{nM}$ comparable to that of isoCA-4 $\left(\mathrm{GI}_{50}=3-5 \mathrm{nM}\right)$, thus clearly indicating an antiproliferative activity regardless of the origin of the tumor cells. To confirm that the antiproliferative activities of these derivatives, like those of CA-4 and isoCA-4, were related to an interaction with the microtubule system, benzoxepins $\mathbf{6 b}, \mathbf{c}, \mathbf{6 e , f}$ and $25 \mathbf{a}$ were evaluated for their inhibitory effects on tubulin assembly (Table 2). As expected, all tested compounds strongly inhibited tubulin assembly with comparable $\mathrm{IC}_{50}$ values of 3.2-3.9 $\mu \mathrm{M}$, which were about two times greater than that of isoCA-4 $\left(\mathrm{IC}_{50}=1.5 \mu \mathrm{M}\right)$. Consistent with earlier observations[66], the replacement of the 4-methoxy group in $6 \mathbf{b}\left(\mathrm{CI}_{50}=3.8 \mu \mathrm{M}\right)$ with an hydrogen atom in $\mathbf{6 c}\left(\mathrm{CI}_{50}=3.2 \mu \mathrm{M}\right)$ had no significant impact on tubulin assembly but reduced cytotoxicity by approximately 10 orders of magnitude.

\subsubsection{Cell Cycle Analysis and Apoptosis}

Because molecules exhibiting activity on tubulin should cause the alteration of cell cycle parameters leading to a preferential $\mathrm{G}_{2} / \mathrm{M}$ blockade,[67] the effect of the most potent benzoxepin $6 \mathbf{b}$ on the cell cycle of K562, MDA-MB231, H1299 and HCT116 cells was then investigated. Cancer cells were cultured without or with $\mathbf{6 b}$ (Figure 3) and cell cycle distribution was analyzed by flow cytometry after $24 \mathrm{~h}$ of treatment using the standard propidium iodide procedure.

\section{$<$ Figure 3>}

Figure 2. Effects of benzoxepin $\mathbf{6 b}$ at a concentration of $5.0 \mathrm{nM}$ on cell cycle distribution in various cancer cell lines.

After treatment with $5 \mathrm{nM}$ of $\mathbf{6 b}$, a net increase in the number of cells arrested at the $\mathrm{G}_{2} / \mathbf{M}$ growth phase was observed. Cell-cycle arrest in the $\mathrm{G}_{2} / \mathrm{M}$ phase is frequently followed by DNA fragmentation and other morphological features of apoptosis. The potency of benzoxepin $\mathbf{6 b}$ to induce apoptosis was further characterized by a specific apoptosis assay. Cleavage of pro-caspases to active caspases is one of the hall marks of apoptosis. HCT116 and H1299 cells were incubated with 1, 5, and $10 \mathrm{nM}$ of $\mathbf{6 b}$ for $24 \mathrm{~h}$ and caspases-3 and -7 activities were evaluated using the standard caspases assays.

\section{$<$ Figure 4>}

Figure 3. Apoptotic effects of $6 \mathbf{b}$ in HCT116 and H1299 cells. The results are expressed in the percentage of apoptotic cells detected following $24 \mathrm{~h}$ of treatment with $\mathbf{6 b}$ at different concentrations.

The results depicted in Figure 4 show a significant dose-dependent increase in proteolytic activity of caspases in HCT116 and H1299 cells treated with $\mathbf{6 b}$ at low concentrations of 5 and $10 \mathrm{nM}$. These data suggest that benzoxepin $\mathbf{6 b}$, in addition to its antiproliferative properties, also induced apoptosis in the tested cancer cell lines.

\subsection{Docking study.}

To rationalize the potential binding mode of benzoxepins $\mathbf{6}$ in tubulin, a docking study was carry out with $\mathbf{6} \mathbf{b}$ as the most potent derivative in this series. For this purpose, the X-ray structure of tubulin-DAMA-colchicine complex (Code PDB: 1sa0)[68] was used. 
Figure 5. Docked pose of $\mathbf{6 b}$ (gray) overlayed with isoCA-4 (blue) in the tubulin binding site.

The docking-derived superimposition of $\mathbf{6 b}$ and isoCA-4 was illustrated in Figure 5, and benzoxepin $\mathbf{6 b}$ showed a binding pose similar to the one observed with isoCA-4. As it was previously observed with CA-4 and isoCA-4, the trimethoxyphenyl ring of $\mathbf{6 b}$ was placed in proximity of Cys241 and the benzoxepin ring in proximity of Val181 to establish a hydrogen bond with its $\mathrm{C} 9-\mathrm{OH}$ substituent.

\section{Conclusion}

We have designed and synthesized a series of benzoxepin compounds 6 as rigid-isoCA-4 analogues and evaluated their biological activities. Compound $\mathbf{6 b}$, the hybrid most closely resembling isoCA-4 in structure, have potent antimitotic and cytotoxic properties. Benzoxepin 6b, which was prepared from isovanillin according to a convergent synthetic strategy in 9 steps (7.8\% overall yield), displayed a nanomolar level of cytotoxicity against various cancer cell lines $\left(\mathrm{GI}_{50}=1.5-8 \mathrm{nM}\right)$, and showed similar antitubulin activities than that of isoCA-4. Flow cytometry analysis indicated that benzoxepin $\mathbf{6 b}$ at a low concentration of $5 \mathrm{nM}$, arrested the cell cycle in the $\mathrm{G}_{2} / \mathrm{M}$ phase in H1299, K562, HCT116 and MDA-MB231 cells. Furthermore, $6 \mathbf{b}$ was characterized as a strong apoptotic agent by inducing the activation of procaspases in HCT116 and H1299 cells. All these results are well supported by molecular modelling studies, where it was observed that benzoxepin $\mathbf{6 b}$ and isoCA-4 can be perfectly superimposed in the tubulin binding-site. On the basis of its excellent properties, compound $\mathbf{6 b}$ is worthy of further in vitro and in vivo evaluations.

\section{Experimental}

\subsection{General considerations}

The synthesis of $\mathbf{6 g}$ was achieved using a Biotage Initiator microwave synthesizer. NMR spectra were performed on a Bruker AVANCE $300\left({ }^{1} \mathrm{H}, 300 \mathrm{MHz} ;{ }^{13} \mathrm{C}, 75 \mathrm{MHz}\right)$ or Bruker AVANCE $400\left({ }^{1} \mathrm{H}, 400 \mathrm{MHz} ;{ }^{13} \mathrm{C}, 100 \mathrm{MHz}\right)$. Unless otherwise stated, CDCl was used as solvent. Chemical shifts $\delta$ are in ppm, and the following abbreviations are used: singlet (s), doublet (d), triplet ( $\mathrm{t}$ ), multiplet (m), doublet of triplet (dt), quintuplet (qt), broad singlet (br s). Elemental analyses (C, H, N) were performed with a PerkinElmer 240 analyzer and were within $0.4 \%$ of the theorical values otherwise stated. Mass spectra were obtained using a Bruker Esquire electrospray ionization apparatus. High resolution mass spectra were recorded on a MicrotofQ Bruker Daltonics. Thin-layer chromatography was performed on silica gel 60 plates with a fluorescent indicator and visualized under a UVP Mineralight UVGL58 lamp $(254 \mathrm{~nm})$ and with a 7\% solution of phosphomolybdic acid in ethanol. Flash chromatography was performed using silica gel 60 (40-63 $\mu \mathrm{m}, 230-400$ mesh ASTM) at medium pressure (200 mbar). All solvents were distilled and stored over $4 \AA$ molecular sieves before use. All reagents were obtained from commercial suppliers unless otherwise stated. Organic extracts were, in general, dried over magnesium sulphate $\left(\mathrm{MgSO}_{4}\right)$ or sodium sulphate $\left(\mathrm{Na}_{2} \mathrm{SO}_{4}\right)$.

\subsection{Synthesis of (1-(2-(but-3-en-1-yloxy)phenyl)vinyl)tributylstannane 9a}

To a solution of 1-(but-3-en-1-yloxy)-2-ethynylbenzene[69] (600 mg, $3.5 \mathrm{mmol})$ in THF (10 mL) were successively added $\mathrm{PdCl}_{2}\left(\mathrm{PPh}_{3}\right)_{2}(246 \mathrm{mg}, 0.35 \mathrm{mmol}, 10 \mathrm{~mol} \%)$ and $\mathrm{Bu} 3 \mathrm{SnH}(1.15 \mathrm{~mL}, 4.2 \mathrm{mmol}, 1.2$ equiv). The mixture was stirred at room temperature for $1 \mathrm{~h}$ and concentrated. Purification by flash chromatography on silica gel (neutralized with $1 \%$ of $\mathrm{Et}_{3} \mathrm{~N}$ ) afforded compound 9a as a colorless oil $(1.25 \mathrm{~g} ; 2.8 \mathrm{mmol} ; 80 \%)$. $\mathrm{R}_{\mathrm{f}}$ (cyclohexane/EtOAc : 9/1) = 0.77. ${ }^{1} \mathrm{H}$ NMR: $\left(\mathrm{CDCl}_{3}, 300 \mathrm{MHz}\right): 7.15$ $(\mathrm{dt}, 1 \mathrm{H}, J=1.8 \mathrm{~Hz}, J=7.6 \mathrm{~Hz}), 7.03(\mathrm{dd}, 1 \mathrm{H}, J=7.5 \mathrm{~Hz}, J=1.8 \mathrm{~Hz}), 6.89(\mathrm{~m}, 1 \mathrm{H}), 6.79(\mathrm{~d}, 1 \mathrm{H}, J=7.6 \mathrm{~Hz}), 5.89-5.86(\mathrm{~m}, 2 \mathrm{H}), 5.39$ $(\mathrm{m}, 1 \mathrm{H}), 5.13(\mathrm{~m}, 2 \mathrm{H}), 4.01(\mathrm{t}, 2 \mathrm{H}, J=7.3 \mathrm{~Hz}), 2.65-2.55(\mathrm{~m}, 2 \mathrm{H}), 1.55-1.30(\mathrm{~m}, 12 \mathrm{H}), 1.20-0.65(\mathrm{~m}, 15 \mathrm{H}) .{ }^{13} \mathrm{C} \mathrm{NMR}(100 \mathrm{MHz}$, $\mathrm{CDCl}_{3}$ ): 155.6, 131.2, 128.3, 126.1, 120.2, 116.6, 113.8, 111.5, 110.8, 67.1, 33.3, 28.7 (3), 26.8 (3), 13.3 (3), 9.8 (3), one C missing. IR (neat): 2955, 2926, 1577, 1464, 1237, 1117, $1030 \mathrm{~cm}^{-1}$. MS (APCI) $[\mathrm{M}+\mathrm{H}]^{+}=465.0$.

\subsection{Synthesis of 1-(but-3-en-1-yloxy)-2-(1-iodovinyl)benzene 10a.}

To a $\mathrm{CH}_{2} \mathrm{Cl}_{2}(10 \mathrm{~mL})$ solution containing $9 \mathrm{a}(597 \mathrm{mg}, 1.29 \mathrm{mmol})$ was added in one portion $\mathrm{I}_{2}(326 \mathrm{mg}, 1.29 \mathrm{mmol})$ at $0^{\circ} \mathrm{C}$. The mixture was then stirred at $\mathrm{rt}$ for $1 \mathrm{~h}$. Then a saturated $\mathrm{KF}$ solution $(10 \mathrm{~mL})$ was added to the mixture which was extracted with $\mathrm{Et}_{2} \mathrm{O}$, washed with a $\mathrm{Na}_{2} \mathrm{~S}_{2} \mathrm{O}_{3}$ solution $\left(10 \mathrm{~mL}\right.$ ). The combined organic layers were dried over $\mathrm{MgSO}_{4}$, filtered, and the solvent was then removed. Purification by flash chromatography afforded compound 10a as a brown oil (213 mg; $0.71 \mathrm{mmol} ; 45 \%$ ). $\mathrm{R}_{\mathrm{f}}$ (cyclohexane/EtOAc : 9/1) = 0.54. ${ }^{1} \mathrm{H}$ NMR: $\left(\mathrm{CDCl}_{3}, 300 \mathrm{MHz}\right)$ : 7.28-7.24 (m, 2H), 6.92-6.82 (m, 2H), $6.28(\mathrm{~s}, 1 \mathrm{H}), 6.14(\mathrm{~s}, 1 \mathrm{H})$, 
$5.94(\mathrm{~m}, 1 \mathrm{H}), 5.19-5.11(\mathrm{~m}, 2 \mathrm{H}), 4.07(\mathrm{~m}, 2 \mathrm{H}), 2.62(\mathrm{~m}, 2 \mathrm{H}) .{ }^{13} \mathrm{C} \mathrm{NMR}\left(100 \mathrm{MHz}, \mathrm{CDCl}_{3}\right): 134.6,130.2,130.1,129.9,120.2,117.7$, 117.3, 117.1, 112.1, 100.5, 67.8, 33.7. IR (neat): 29272927, 1661, 1594, 1487, 1447, 1283, 1243, 1162, $1113 \mathrm{~cm}^{-1}$. MS (APCI) $[\mathrm{M}+\mathrm{H}]^{+}=301.0$.

4.4 Synthesis of 1-iodo-3-isopropoxy-4-methoxy-2-(methoxymethoxy)benzene 16.

Phenol 15[Erreur ! Signet non défini.] (1.5 g, $4.86 \mathrm{mmol})$ was mixed with $\mathrm{Et}_{2} \mathrm{NH}(1.41 \mathrm{~mL} ; 9.72 \mathrm{mmol})$ and $\mathrm{MOMCl}(0.75 \mathrm{~mL}$; $9.72 \mathrm{mmol})$ in $\mathrm{CH}_{2} \mathrm{Cl}_{2}(15 \mathrm{~mL})$ for $1 \mathrm{~h}$ at room temperature. The medium was quenched with $\mathrm{H}_{2} \mathrm{O}(45 \mathrm{~mL})$ and extracted with $\mathrm{CH}_{2} \mathrm{Cl}_{2}$ (3 x $15 \mathrm{~mL}$ ). The combined organic layers were dried over $\mathrm{MgSO}_{4}$, filtered, and the solvent was then removed. Purification by flash chromatography afforded compound 16 as a colorless oil $(1.67 \mathrm{~g} ; 4.77 \mathrm{mmol} ; 98 \%)$. $\mathrm{R}_{\mathrm{f}}($ cyclohexane/EtOAc: $8 / 2)=0.68 .{ }^{1} \mathrm{H}$ NMR: $\left(\mathrm{CDCl}_{3}, 300 \mathrm{MHz}\right): 7.36(\mathrm{~d}, 1 \mathrm{H}, J=8.8 \mathrm{~Hz}) 6.42(\mathrm{~d}, 1 \mathrm{H}, J=8.8 \mathrm{~Hz}), 5.14(\mathrm{~s}, 2 \mathrm{H}), 4.33(\mathrm{~m}, 1 \mathrm{H}), 3.75(\mathrm{~s}, 3 \mathrm{H}), 3.60(\mathrm{~s}, 3 \mathrm{H})$, $1.21(\mathrm{~d}, 6 \mathrm{H}, J=6.2 \mathrm{~Hz}) .{ }^{13} \mathrm{C} \mathrm{NMR}\left(100 \mathrm{MHz}, \mathrm{CDCl}_{3}\right): 155.0,140.1,132.8,124.0,109.7,99.3,81.5,75.9,58.6,56.1,22.4$ (2C). MS $(\mathrm{ESI})[\mathrm{M}+\mathrm{Na}]^{+}=375.0$.

4.5 Synthesis of 4-(3-isopropoxy-4-methoxy-2-(methoxymethoxy)phenyl)but-3-yn-1-ol 17.

A solution of 16 (700 mg; $2 \mathrm{mmol})$, but-3-yn-1-ol (0.2 mL, $2.42 \mathrm{mmol}), \mathrm{PdCl}_{2}\left(\mathrm{PPh}_{3}\right)_{2},(112 \mathrm{mg}$; $0.16 \mathrm{mmol}), \mathrm{CuI}(44 \mathrm{mg} ; 0.30$ $\mathrm{mmol})$ was stirred in $\mathrm{Et}_{3} \mathrm{~N}(10 \mathrm{~mL})$ for $2 \mathrm{~h}$ at room temperature. EtOAc $(20 \mathrm{~mL})$ was added to the crude mixture which was washed with a saturated $\mathrm{NH}_{4} \mathrm{Cl}$ solution. After extraction with $\mathrm{CH}_{2} \mathrm{Cl}_{2}$, the combined extracts were dried $\left(\mathrm{MgSO}_{4}\right)$ and concentrated. Purification by flash chromatography on silica gel afforded alkyne $\mathbf{1 7}$ as a brown oil (538 $\mathrm{mg} ; 1.80 \mathrm{mmol} ; 90 \%)$. $\mathrm{R}_{\mathrm{f}}$ (cyclohexane/EtOAc: $7 / 3)=0.22 .{ }^{1} \mathrm{H}$ NMR: $\left(\mathrm{CDCl}_{3}, 300 \mathrm{MHz}\right): 7.09(\mathrm{~d}, 1 \mathrm{H}, J=8.6 \mathrm{~Hz}), 6.61(\mathrm{~d}, 1 \mathrm{H}, J=8.6 \mathrm{~Hz}), 5.23(\mathrm{~s}, 2 \mathrm{H}), 4.39$ $(\mathrm{m}, 1 \mathrm{H}), 3.83(\mathrm{~s}, 3 \mathrm{H}), 3.80(\mathrm{t}, 2 \mathrm{H}, J=6.2 \mathrm{~Hz}), 3.61(\mathrm{~s}, 3 \mathrm{H}), 2.69(\mathrm{t}, 2 \mathrm{H}, J=6.2 \mathrm{~Hz}), 1.27(\mathrm{~d}, 6 \mathrm{H}, J=6.2 \mathrm{~Hz}), \mathrm{OH}$ not seen. ${ }^{13} \mathrm{C} \mathrm{NMR}$ (100 MHz, $\mathrm{CDCl}_{3}$ ): 154.6, 127.7, 114.9, 110.8, 107.4, 99.0, 97.3, 88.9, 78.9, 75.6, 61.1, 57.6, 55.9, 24.1, 22.4 (2C). IR (neat): 3894, $3807,3634,3489,2976,2106,2021,1594,1491,1437,1381,1290,1207,1157,1099,1060,968,921,803,774,693 \mathrm{~cm}^{-1}$. MS (ESI) $[\mathrm{M}+\mathrm{Na}]^{+}=317.0$.

4.6 Synthesis of 4-hydroxy-1-(2-hydroxy-3-isopropoxy-4-methoxyphenyl)butan-1-one 18.

To a solution of 17 (400 mg; $1.36 \mathrm{mmol})$ in EtOH (272 $\mu \mathrm{L}$ ) was added PTSA (260 mg; $1.36 \mathrm{mmol})$ and $\mathrm{H}_{2} \mathrm{O}(2.45 \mathrm{~mL})$. The solution was then stirred at $100^{\circ} \mathrm{C}$ in a sealed tube for $0.5 \mathrm{~h}$. After cooling, the crude mixture was extracted with $\mathrm{CH}_{2} \mathrm{Cl}_{2}$. The organic layers were dried over $\mathrm{MgSO}_{4}$, filtered, and the solvent was then removed. Purification by flash chromatography afforded compound $\mathbf{1 8}$ as a brown oil (228 mg; $0.84 \mathrm{mmol} ; 62 \%)$. $\mathrm{R}_{\mathrm{f}}$ (cyclohexane/EtOAc: 5/5) = 0.30. ${ }^{1} \mathrm{H}$ NMR: $\left(\mathrm{CDCl}_{3}, 300 \mathrm{MHz}\right): 12.53$ (brs, $\left.1 \mathrm{H}\right), 7.53$ (d, $1 \mathrm{H}, J=9.1 \mathrm{~Hz}), 6.46(\mathrm{~d}, 1 \mathrm{H}, J=9.1 \mathrm{~Hz}), 4.43(\mathrm{~m}, 1 \mathrm{H}), 3.88(\mathrm{~s}, 3 \mathrm{H}), 3.71(\mathrm{t}, 2 \mathrm{H}, J=6.1 \mathrm{~Hz}), 3.05(\mathrm{t}, 2 \mathrm{H}, J=7.1 \mathrm{~Hz}), 1.97(\mathrm{~m}, 2 \mathrm{H})$, 1.29 (d, $6 \mathrm{H}, J=6.2 \mathrm{~Hz}), \mathrm{OH}$ not seen. ${ }^{13} \mathrm{C} \mathrm{NMR}\left(100 \mathrm{MHz}, \mathrm{CDCl}_{3}\right): 205.2,158.9, .157 .6,134.5,126.0,114.7,102.8,75.1,61.9,55.9$, 34.5, 27.1, 22.4 (2C). IR (neat): 2976, 1631, 1505, 1429, 1261, 1131, 1092, 944, 685, $619 \mathrm{~cm}^{-1}$. MS (APCI) $[\mathrm{M}+\mathrm{H}]^{+}=269.0$.

4.7 Synthesis of 9-isopropoxy-8-methoxy-3,4-dihydrobenzo[b]oxepin-5(2H)-one 19.

Compound 18 (300 mg; $1.11 \mathrm{mmol})$ was stirred for $1 \mathrm{~h}$ with DEAD $(0.27 \mathrm{~mL} ; 1.68 \mathrm{mmol})$ and $\mathrm{PPh}_{3}(441 \mathrm{mg} ; 1.68 \mathrm{mmol})$ in THF $(30 \mathrm{~mL})$. After concentration under reduced pressure, the crude mixture was purified by flash chromatography to afford benzoxepin5-one 19 as a pale yellow oil $(174 \mathrm{mg} ; 0.69 \mathrm{mmol} ; 63 \%)$. Rf (cyclohexane/EtOAc: 5/5) = 0.60. ${ }^{1} \mathrm{H} \mathrm{NMR:}\left(\mathrm{CDCl}_{3}, 300 \mathrm{MHz}\right): 7.51(\mathrm{~d}$, $1 \mathrm{H}, J=8.9 \mathrm{~Hz}), 6.66(\mathrm{~d}, 1 \mathrm{H}, J=8.9 \mathrm{~Hz}), 4.34(\mathrm{~m}, 1 \mathrm{H}), 4.22(\mathrm{t}, 2 \mathrm{H}, J=6.7 \mathrm{~Hz}), 3.85(\mathrm{~s}, 3 \mathrm{H}), 2.83(\mathrm{t}, 2 \mathrm{H}, J=6.9 \mathrm{~Hz}), 2.15(\mathrm{~m}, 2 \mathrm{H})$, $1.28(\mathrm{~d}, 6 \mathrm{H}, J=6.2 \mathrm{~Hz}) .{ }^{13} \mathrm{C} \mathrm{NMR}\left(100 \mathrm{MHz}, \mathrm{CDCl}_{3}\right):$ 199.4, 157.7, 156.6, 137.9, 124.4, 123.9, 106.4, 75.7, 72.8, 55.9, 40.2, 25.9, 22.4 (2C). IR (neat): 2975, 2023, 1674, 1587, 1493, 1433, 1372, 1270, 1218, 1196, 1169, 1093, 1008, $964 \mathrm{~cm}^{-1}$. MS (ESI) [M+Na] ${ }^{+}$ $=273.1$.

4.8 Synthesis of N'-(9-isopropoxy-8-methoxy-3,4-dihydrobenzo[b]oxepin-5(2H)-ylidene)-4-methylbenzenesulfonohydrazide 11a.

To a solution of benzoxepin-5-one 19 (173 mg; $0.69 \mathrm{mmol})$ and PTSA (28 mg; $0.14 \mathrm{mmol})$ in ethanol (5 mL) was added 4methylbenzenesulfonohydrazide ( $321 \mathrm{mg} ; 1.72 \mathrm{mmol}$ ). The resulting mixture was stirred under reflux for $1 \mathrm{~h}$. The medium was diluted with EtOAc and filtered over a pad of Celite. The solvent was next removed and the residue was purified by crystallization in ethanol to afford 11a as a white solid $(147 \mathrm{mg} ; 0.35 \mathrm{mmol} ; 51 \%)$. $\mathrm{R}_{\mathrm{f}}$ (cyclohexane/EtOAc: $\left.5 / 5\right)=0.60 . \mathrm{F}=192-194{ }^{\circ} \mathrm{C} .{ }^{1} \mathrm{H}$ NMR: $\left(\mathrm{CDCl}_{3}, 300 \mathrm{MHz}\right): 7.76(\mathrm{~d}, 2 \mathrm{H}, J=8.1 \mathrm{~Hz}), 7.60(\mathrm{brs}, 1 \mathrm{H}), 7.31(\mathrm{~d}, 2 \mathrm{H}, J=8.1 \mathrm{~Hz}), 6.87(\mathrm{~d}, 1 \mathrm{H}, J=8.3 \mathrm{~Hz}), 6.53(\mathrm{~d}, 1 \mathrm{H}, J=8.3$ $\mathrm{Hz}), 4.20(\mathrm{~m}, 1 \mathrm{H}), 4.10(\mathrm{~m}, 1 \mathrm{H}), 3.80(\mathrm{~m}, 1 \mathrm{H}), 3.76(\mathrm{~s}, 3 \mathrm{H}), 2.60(\mathrm{t}, 2 \mathrm{H}, J=6.8 \mathrm{~Hz}), 2.37(\mathrm{~s}, 3 \mathrm{H}), 1.80(\mathrm{~m}, 2 \mathrm{H}), 1.19(\mathrm{~d}, 6 \mathrm{H}, J=6.3$ 
Hz). ${ }^{13} \mathrm{C}$ NMR (100 MHz, $\left.\mathrm{CDCl}_{3}\right):$ 157.1, 155.3, 151.6, 144.1, 138.8, 135.5, 129.7 (2C), 128.2 (2C), 123.9, 122.8, 107.1, 75.8, 71.0, 56.1, 26.3, 24.9, 22.5 (2C), 21.7. IR (neat): 3803, 3676, 2972, 1595, 1494, 1435, 1373, 1321, 1288, 1219, 1164, 1097, 911, 812, 728, $665 \mathrm{~cm}^{-1}$. MS (APCI) $[\mathrm{M}+\mathrm{H}]^{+}=419.0$.

4.9 Synthesis of 3-bromo-2-hydroxy-4-methoxybenzaldehyde 20[70]

To a solution of isovanillin $(2.5 \mathrm{~g} ; 21.55 \mathrm{mmol})$ in EtOH $(25 \mathrm{~mL})$ were added a drop of AcOH and $\mathrm{Hg}(\mathrm{OAc})_{2}(6.85 \mathrm{~g} ; 21.55 \mathrm{mmol})$. After 20 min of stirring at $50^{\circ} \mathrm{C}$, an aqueous solution of $\mathrm{NaBr}(2.21 \mathrm{~g} ; 21.55 \mathrm{mmol})$ was added and the precipitate was filtered. This latter was dissolved in $\mathrm{CH}_{3} \mathrm{CN}$ and MPHT $(8.45 \mathrm{~g} ; 21.55 \mathrm{mmol})$ was added in one portion. After 20 min of stirring at room temperature, the medium was concentrated and hydrolyzed with a saturated aqueous $\mathrm{NaHCO}_{3}$ solution. After extraction with EtOAc $(3 \times 100 \mathrm{~mL})$, the combined extracts were dried $\left(\mathrm{MgSO}_{4}\right)$ and concentrated. Purification by flash chromatography on silica gel afforded 20 as a beige solid $(2.34 \mathrm{~g} ; 12.05 \mathrm{mmol} ; 56 \%)$.

4.10 Synthesis of 2-(allyloxy)-3-bromo-4-methoxybenzaldehyde 21.

To a $\mathrm{CH}_{3} \mathrm{CN}$ solution of 20 (4.6 g; $20 \mathrm{mmol}$ ) was added $\mathrm{K}_{2} \mathrm{CO}_{3}(3.32 \mathrm{~g} ; 24 \mathrm{mmol})$ and allylbromide $(2.08 \mathrm{~mL} ; 24 \mathrm{mmol})$. The mixture was stirred for $1 \mathrm{~h}$ under reflux and after cooling to room temperature, the medium was filtered, concentrated and hydrolyzed with $\mathrm{H}_{2} \mathrm{O}$. After extraction with EtOAc, the combined extracts were dried $\left(\mathrm{MgSO}_{4}\right)$ and concentrated. Purification by flash chromatography on silica gel afforded 21 as a colorless oil $(5.2 \mathrm{~g} ; 19.2 \mathrm{mmol}, 96 \%)$. $\mathrm{R}_{\mathrm{f}}\left(\right.$ cyclohexane/EtOAc: 8/2) $=0.48$. ${ }^{1} \mathrm{H}$ NMR: $\left(\mathrm{CDCl}_{3}, 300 \mathrm{MHz}\right): 10.15(\mathrm{~s}, 1 \mathrm{H}), 7.77(\mathrm{~d}, 1 \mathrm{H}, J=8.8 \mathrm{~Hz}), 6.74(\mathrm{~d}, 1 \mathrm{H}, J=8.8 \mathrm{~Hz}), 6.06(\mathrm{~m}, 1 \mathrm{H}), 5.36-5.26(\mathrm{~m}, 2 \mathrm{H}), 4.55(\mathrm{~m}, 2 \mathrm{H})$, 3.91 (s, 3H). ${ }^{13} \mathrm{C}$ NMR (100 MHz, $\mathrm{CDCl}_{3}$ ): 188.3, 162.2, 160.5, 132.2, 128.8, 124.6, 119.6, 107.9, 107.5, 76.6, 56.8. IR (neat): 3082, $2938,2847,2362,1675,1584,1485,1452,1437,1414,1391,1359,1291,1246,1199,1178,1127,1073 \mathrm{~cm}^{-1}$. MS $(\mathrm{APCI})[\mathrm{M}+\mathrm{H}]^{+}=$ $271.0\left({ }^{79} \mathrm{Br}\right), 273.5\left({ }^{81} \mathrm{Br}\right)$.

4.11 Synthesis of 1-(2-(allyloxy)-3-bromo-4-methoxyphenyl)prop-2-en-1-ol 13a.

To a solution of $21(1.0 \mathrm{~g} ; 3.7 \mathrm{mmol})$ in THF $(10 \mathrm{~mL})$ was added at $0^{\circ} \mathrm{C} 4.5 \mathrm{~mL}$ of a $1 \mathrm{~N}$ solution of vinylmagnesium bromide $(4.5$ mmol) in THF. After stirring for $1 \mathrm{~h}$ at room temperature, the medium was hydrolyzed with $\mathrm{H}_{2} \mathrm{O}$. After extraction with $\mathrm{CH}_{2} \mathrm{Cl}_{2}$, the combined extracts were dried $\left(\mathrm{MgSO}_{4}\right)$ and concentrated. Purification by flash chromatography on silica gel afforded 13a as a yellow oil $\left(1.05 \mathrm{~g}\right.$; $3.51 \mathrm{mmol}$; 95\%). $\mathrm{R}_{\mathrm{f}}$ (cyclohexane/EtOAc: 7/3) = 0.50. ${ }^{1} \mathrm{H}$ NMR: $\left(\mathrm{CDCl}_{3}, 300 \mathrm{MHz}\right): 7.22(\mathrm{~d}, 1 \mathrm{H}, J=8.7 \mathrm{~Hz}), 6.64(\mathrm{~d}$, $1 \mathrm{H}, J=8.7 \mathrm{~Hz}), 6.16-5.90(\mathrm{~m}, 2 \mathrm{H}), 5.43-5.13(\mathrm{~m}, 5 \mathrm{H}), 4.47(\mathrm{~m}, 2 \mathrm{H}), 3.81(\mathrm{~s}, 3 \mathrm{H}), 2.40(\mathrm{~d}, 1 \mathrm{H}, J=5.4 \mathrm{~Hz}) .{ }^{13} \mathrm{C} \mathrm{NMR}(100 \mathrm{MHz}$, $\mathrm{CDCl}_{3}$ ): 156.8, 154.8, 139.7, 133.2, 129.9, 127.0, 118.2, 114.9, 107.8, 107.3, 74.7, 69.8, 56.5. IR (neat): 2947, 1675, 1584, 1485, $1319,1291,1246,1199,1178,1127,998 \mathrm{~cm}^{-1}$. MS (APCI) $[\mathrm{M}+\mathrm{H}]^{+}=299.1\left({ }^{79} \mathrm{Br}\right), 301.1\left({ }^{81} \mathrm{Br}\right)$.

4.12 Synthesis of 9-bromo-8-methoxy-2,5-dihydrobenzo[b]oxepin-5-ol 22

Compound 13a $(828 \mathrm{mg} ; 2.79 \mathrm{mmol})$ was stirred under argon with Grubbs II catalyst ([1,3-bis-(2,4,6-trimethylphenyl)-2imidazolidinylidene]dichloro(phenylmethylene)(tricyclohexylphosphine)ruthenium, $231 \mathrm{mg}$; $0.27 \mathrm{mmol}$ ) in $\mathrm{CH}_{2} \mathrm{Cl}_{2}(60 \mathrm{~mL})$ for $1 \mathrm{~h}$ at room temperature. The crude mixture was concentrated and the residue was purified by flash chromatography on silica gel to afford 22 as a colorless oil (558 mg; $2.04 \mathrm{mmol} ; 73 \%)$. $\mathrm{R}_{\mathrm{f}}$ (cyclohexane/EtOAc: 7/3) = 0.30. ${ }^{1} \mathrm{H} \mathrm{NMR:}\left(\mathrm{CDCl}_{3}, 300 \mathrm{MHz}\right): 7.11(\mathrm{~d}$, $1 \mathrm{H}, J=8.6 \mathrm{~Hz}), 6.55(\mathrm{~d}, 1 \mathrm{H}, J=8.6 \mathrm{~Hz}), 5.87(\mathrm{~m}, 1 \mathrm{H}), 5.34-5.30(\mathrm{~m}, 2 \mathrm{H}), 4.50(\mathrm{~m}, 2 \mathrm{H}), 3.80(\mathrm{~s}, 3 \mathrm{H}), 2.80(\mathrm{~d}, 1 \mathrm{H}, J=7.0 \mathrm{~Hz}, \mathrm{OH})$. ${ }^{13} \mathrm{C} \mathrm{NMR}\left(100 \mathrm{MHz}, \mathrm{CDCl}_{3}\right.$ ): 156.4, 153.6, 133.0, 131.8, 127.1, 124.2, 107.2, 106.5, 69.8, 68.5, 56.5. IR (neat): 2362, 1675, 1584, $1291,1246,1199,1178,1127,1073,956,873 \mathrm{~cm}^{-1}$. MS (APCI) $[\mathrm{M}+\mathrm{H}]^{+}=271.3\left({ }^{79} \mathrm{Br}\right), 273.0\left({ }^{81} \mathrm{Br}\right)$.

4.13 Synthesis of 9-bromo-8-methoxy-2,3,4,5-tetrahydrobenzo[b]oxepin-5-ol 23

A mixture of 22 (480 mg, $1.76 \mathrm{mmol}), \mathrm{Pd} / \mathrm{C}(48 \mathrm{mg}), \mathrm{MeOH}(20 \mathrm{~mL})$ and 1 drop of $\mathrm{AcOH}$ was stirred under an $\mathrm{H}_{2}$ atmosphere for 1 $\mathrm{h}$ at room temperature. The mixture was then filtered over a pad of Celite and concentrated. Purification by flash chromatography on silica gel afforded 23 as a colorless oil $(318 \mathrm{mg} ; 1.16 \mathrm{mmol} ; 66 \%)$. $\mathrm{R}_{\mathrm{f}}\left(\right.$ cyclohexane/EtOAc: 9/1) $=0.33 .{ }^{1} \mathrm{H}$ NMR: $\left(\mathrm{CDCl}_{3}, 300\right.$ MHz): 7.24 (d, 1H, $J=7.2 \mathrm{~Hz}), 6.61(\mathrm{~d}, 1 \mathrm{H}, J=7.2 \mathrm{~Hz}), 4.86(\mathrm{~m}, 1 \mathrm{H}), 4.17-3.99$ (m, 2H), 3.87 (s, 3H), 2.50-2.15 (m, 2H), 2.10-1.93 (m, 2H), OH not seen. ${ }^{13} \mathrm{C}$ NMR (100 MHz, $\left.\mathrm{CDCl}_{3}\right)$ : 156.3, 156.1, 131.3, 126.3, 106.7, 76.4, 73.3, 72.5, 56.6, 34.2, 27.0. IR (neat): $2978,1595,1490,1435,1355,1321,1288,1231,1206,1164,812,730,665,641 \mathrm{~cm}^{-1}$. MS (APCI) $[\mathrm{M}+\mathrm{H}]^{+}=273.0\left({ }^{79} \mathrm{Br}\right), 275.1$ $\left({ }^{81} \mathrm{Br}\right)$. 
To a solution of $23(240 \mathrm{mg} ; 0.87 \mathrm{mmol})$ in $\mathrm{CH}_{2} \mathrm{Cl}_{2}(15 \mathrm{~mL})$ was added in 3 portions PCC $(192 \mathrm{mg})$ at the begining of the reaction, a second drop of PCC (192 mg) was next added to the mixture after $1 \mathrm{~h}$ of stirring and a last drop of PCC (96 mg) was finally added to complete the oxidation reaction after $3 \mathrm{~h}$ of stirring. The mixture was filtered over a pad of Celite and concentrated. Purification by flash chromatography on silica gel afforded 24 as brown oil $(228 \mathrm{mg} ; 0.84 \mathrm{mmol} ; 96 \%)$. Rf (cyclohexane/EtOAc: $8 / 2)=0.60 .{ }^{1} \mathrm{H}$ NMR: $\left(\mathrm{CDCl}_{3}, 300 \mathrm{MHz}\right): 7.83(\mathrm{~d}, 1 \mathrm{H}, J=8.8 \mathrm{~Hz}), 6.77(\mathrm{~d}, 1 \mathrm{H}, J=8.8 \mathrm{~Hz}), 4.38(\mathrm{t}, 2 \mathrm{H}, J=6.8 \mathrm{~Hz}), 4.02(\mathrm{~s}, 3 \mathrm{H}), 2.94(\mathrm{t}, 2 \mathrm{H}, J=$ $6.8 \mathrm{~Hz}), 2.27$ (m, 2H). ${ }^{13} \mathrm{C}$ NMR (100 MHz, $\left.\mathrm{CDCl}_{3}\right): 198.8,160.6,159.5,129.6,124.0,106.4,104.7,73.0,56.7$, 40.1, 25.6. IR (neat): $2813,1795,1490,1462,1399,1321,1287,1219,1164,812,728,652 \mathrm{~cm}^{-1}$. MS (APCI) $[\mathrm{M}+\mathrm{H}]^{+}=271.4\left({ }^{79} \mathrm{Br}\right), 273.5\left({ }^{81} \mathrm{Br}\right)$.

4.15 Synthesis of N'-(9-bromo-8-methoxy-3,4-dihydrobenzo[b]oxepin-5(2H)-ylidene)-4-methylbenzenesulfonohydrazide 11b

A solution of 24 (665 mg; $2.5 \mathrm{mmol}$ ), PTSA (53 mg; $0.25 \mathrm{mmol}$ ), $\mathrm{MgSO}_{4}$ (296 mg; $2.5 \mathrm{mmol}$ ) 4-methylbenzenesulfonohydrazide (460 mg; $2.5 \mathrm{mmol}$ ) was stirred under reflux for $2 \mathrm{~h}$. The medium was filtered over a pad of Celite, concentrated, diluted with EtOAc and washed with $\mathrm{H}_{2} \mathrm{O}(3 \times 10 \mathrm{~mL})$. After extraction, the crude was precipitated in EtOH to afford $\mathbf{1 1 b}$ as a white solid (0.98 g; 2.22 mmol, 88\%). Rf $($ cyclohexane/EtOAc: $7 / 3)=0.30 . \mathrm{F}=201-203{ }^{\circ} \mathrm{C} .{ }^{1} \mathrm{H}$ NMR: $\left(\mathrm{CDCl}_{3}, 300 \mathrm{MHz}\right): 8.14(\mathrm{~s}, 1 \mathrm{H}, \mathrm{NH}), 7.71(\mathrm{~d}, 2 \mathrm{H}, J=$ $8.0 \mathrm{~Hz}), 7.24(\mathrm{~d}, 1 \mathrm{H}, J=8.8 \mathrm{~Hz}), 7.13(\mathrm{~d}, 2 \mathrm{H}, J=8.0 \mathrm{~Hz}), 6.46(\mathrm{~d}, 1 \mathrm{H}, J=8.8 \mathrm{~Hz}), 3.95(\mathrm{t}, 2 \mathrm{H}, J=6.6 \mathrm{~Hz}), 3.71(\mathrm{~s}, 3 \mathrm{H}), 2.43(\mathrm{t}, 2 \mathrm{H}$, $J=6.6 \mathrm{~Hz}), 2.23(\mathrm{~s}, 3 \mathrm{H}), 1.75(\mathrm{~m}, 2 \mathrm{H}) .{ }^{13} \mathrm{C} \mathrm{NMR}\left(100 \mathrm{MHz}, \mathrm{CDCl}_{3}\right): 158.2,155.9,154.2,144.2,135.3,129.6,128.0,127.9,124.3$ (2C), 107.0, 105.4, 70.8, 56.5, 26.1, 24.2, 21.6, one C missing. IR (neat): 2967, 1595, 1494, 1435, 1373, 1321, 1288, 1219, 1164, $812,728,665 \mathrm{~cm}^{-1}$. MS (APCI) $[\mathrm{M}+\mathrm{H}]^{+}=439.0\left({ }^{79} \mathrm{Br}\right), 441.0\left({ }^{81} \mathrm{Br}\right)$.

4.16 Synthesis of 9-isopropoxy-8-methoxy-5-(3,4,5-trimethoxyphenyl)-2,3-dihydrobenzo[b]oxepin $\mathbf{6 a}$

To a dioxane $(2 \mathrm{~mL})$ solution of $N$-tosylhydrazone 11a (60 mg, $0.14 \mathrm{mmol}), t \mathrm{BuOLi}$ (23 mg; $0.28 \mathrm{mmol})$ ), $\mathrm{Pd}_{2} \mathrm{dba}_{3}(13 \mathrm{mg}$; 0.014 $\mathrm{mmol}$ ), and XPhos (13 mg; $0.028 \mathrm{mmol}$ ) was added 3,4,5-trimethoxyphenyliodide (42 $\mathrm{mg}, 0.14 \mathrm{mmol}$ ). The mixture was stirred at 90 ${ }^{\circ} \mathrm{C}$ in a sealed tube for $1 \mathrm{~h}$. After cooling at room temperature, the crude mixture was filtered over a pad of Celite and concentrated. The residue was purified by silica gel chromatography to yield $6 \mathbf{6}$ as a brown oil (55 $\mathrm{mg} ; 0.137 \mathrm{mmol} ; 98 \%$ ). $\mathrm{R}_{\mathrm{f}}$ (cyclohexane/EtOAc: 7/3) = 0.60. ${ }^{1} \mathrm{H}$ NMR: $\left(\mathrm{CDCl}_{3}, 400 \mathrm{MHz}\right): 6.65(\mathrm{~d}, 1 \mathrm{H}, J=8.8 \mathrm{~Hz}), 6.56(\mathrm{~d}, 1 \mathrm{H}, J=8.8 \mathrm{~Hz}), 6.50(\mathrm{~s}, 2 \mathrm{H}), 6.14$ $(\mathrm{t}, 1 \mathrm{H}, J=5.9 \mathrm{~Hz}), 4.48-4.43(\mathrm{~m}, 3 \mathrm{H}), 3.87(\mathrm{~s}, 3 \mathrm{H}), 3.83(\mathrm{~s}, 3 \mathrm{H}), 3.81(\mathrm{~s}, 6 \mathrm{H}), 2.50(\mathrm{~m}, 2 \mathrm{H}), 1.35(\mathrm{~d}, 6 \mathrm{H}, J=5.6 \mathrm{~Hz}) .{ }^{13} \mathrm{C} \mathrm{NMR}(100$ $\mathrm{MHz}, \mathrm{CDCl}_{3}$ ): 153.3, 152.8 (2C), 152.2, 141.2, 139.7 (2C), 138.9, 137.3, 126.3, 125.3, 106.5, 106.0 (2C), 76.5, 75.8, 60.9, 56.1 (2C), 55.9, 30.4, 22.7 (2C). IR (neat): 2936, 1710, 1659, 1582, 1549, 1493, 1411, $1232 \mathrm{~cm}^{-1}$. MS (APCI) $[\mathrm{M}+\mathrm{H}]^{+}=401.0$.

4.17 Synthesis of 8-Methoxy-5-(3,4,5-trimethoxyphenyl)-2,3-dihydrobenzo[b]oxepin-9-ol 6b

According to Scheme 2: A solution of $6 \mathbf{a}(110 \mathrm{mg}$; $0.28 \mathrm{mmol})$ in $\mathrm{CH}_{2} \mathrm{Cl}_{2}(5 \mathrm{~mL})$ was stirred with $\mathrm{AlCl}_{3}(92 \mathrm{mg}$; $0.28 \mathrm{mmol})$ for $1 \mathrm{~h}$ at room temperature. Then another portion of $\mathrm{AlCl}_{3}(92 \mathrm{mg})$ was added to the crude mixture. After $1 \mathrm{~h}$ of stirring, the medium was hydrolyzed by $\mathrm{H}_{2} \mathrm{O}(10 \mathrm{~mL})$. After extraction with $\mathrm{CH}_{2} \mathrm{Cl}_{2}(3 \times 10 \mathrm{~mL})$, the combined extracts were dried $\left(\mathrm{MgSO}_{4}\right)$ and concentrated. Purification by flash chromatography on silica gel afforded benzoxepin $\mathbf{6 b}$ as a pale yellow oil (16 mg; $0.04 \mathrm{mmol} ; 15 \%)$.

According to Scheme 3: A solution of $6 \mathbf{d}(100 \mathrm{mg}$; $0.24 \mathrm{mmol}), \mathrm{KOH}$ (5 mmol), $\mathrm{Pd}_{2} \mathrm{dba}_{3}(46 \mathrm{mg} ; 0.005 \mathrm{mmol})$ and $t \mathrm{BuXPhos}(8 \mathrm{mg}$; $0.015 \mathrm{mmol})$ in a mixture of dioxane/ $\mathrm{H}_{2} \mathrm{O}: 1 / 1(2 \mathrm{~mL})$ was stirred at $90{ }^{\circ} \mathrm{C}$ in a sealed tube. After $1 \mathrm{~h}$, the medium was cooled to room temperature, quenched with $\mathrm{NH}_{4} \mathrm{Cl}(10 \mathrm{~mL})$ and extracted with EtOAc $(3 \times 10 \mathrm{~mL})$. The combined organic layers were then dried over $\mathrm{MgSO}_{4}$, filtered and evaporated to dryness. Purification by flash chromatography afforded compound $6 \mathbf{b}$ as a pale yellow oil (47 mg, $0.13 \mathrm{mmol}, 55 \%)$. Rf (cyclohexane/EtOAc: 7/3) = 0.26. ${ }^{1} \mathrm{H} \mathrm{NMR}:\left(\mathrm{CDCl}_{3}, 300 \mathrm{MHz}\right)$ : $6.51(\mathrm{~d}, 1 \mathrm{H}, J=8.8 \mathrm{~Hz}), 6.42(\mathrm{~m}$, $3 \mathrm{H}), 6.08(\mathrm{t}, 1 \mathrm{H}, J=5.9 \mathrm{~Hz}), 5.73(\mathrm{br} \mathrm{s}, 1 \mathrm{H}, \mathrm{OH}), 4.47(\mathrm{t}, 2 \mathrm{H}, J=5.9 \mathrm{~Hz}), 3.83(\mathrm{~s}, 3 \mathrm{H}), 3.80(\mathrm{~s}, 3 \mathrm{H}), 3.74(\mathrm{~s}, 6 \mathrm{H}), 2.49(\mathrm{q}, 2 \mathrm{H}, J=$ $5.9 \mathrm{~Hz}) .{ }^{13} \mathrm{C} \mathrm{NMR}\left(100 \mathrm{MHz}, \mathrm{CDCl}_{3}\right)$ : 152.8 (2C), 146.7, 144.7, 141.2, 138.6 (2C), 137.6, 126.2, 125.0, 121.3, 106.3, 106.0 (2C), 76.6, 60.9, 56.1 (3C). 30.3, IR (neat): 3853, 3618, 3441, 2937, 1580, 1504, 1444, 1411, 1333, 1233, 1124, 1089, $1007 \mathrm{~cm}-1 . \mathrm{MS}$ $(\mathrm{APCI})[\mathrm{M}+\mathrm{H}]^{+}=359.2$. HRMS calcd for $\mathrm{C}_{20} \mathrm{H}_{23} \mathrm{O}_{6}[\mathrm{M}+\mathrm{H}]^{+} 359.1495$, obsd 359.1510 .

4.18 Synthesis of 5-(3,5-dimethoxyphenyl)-8-methoxy-2,3-dihydrobenzo[b]oxepin-9-ol 6c

To a dioxane $(1 \mathrm{~mL})$ solution of $N$-tosylhydrazone 11a (100 mg, $0.24 \mathrm{mmol}), t \mathrm{BuOLi}(38 \mathrm{mg} ; 0.48 \mathrm{mmol})$ ), $\mathrm{Pd}_{2} \mathrm{dba}_{3}(20 \mathrm{mg} ; 0.02$ $\mathrm{mmol}$ ), and XPhos (20 mg; $0.04 \mathrm{mmol}$ ) was added 3,5-dimethoxyphenyliodide (52 mg, $0.24 \mathrm{mmol}$ ). The mixture was stirred at $90{ }^{\circ} \mathrm{C}$ in a sealed tube for $1 \mathrm{~h}$. After cooling, the crude mixture was diluted in $\mathrm{CH}_{2} \mathrm{Cl}_{2}$ and stirred for $2 \mathrm{~h}$ with $\mathrm{AlCl}_{3}(22 \mathrm{mg} ; 0.24 \mathrm{mmol})$. 
The medium was then hydrolyzed by $\mathrm{H}_{2} \mathrm{O}(10 \mathrm{~mL})$. After extraction with $\mathrm{CH}_{2} \mathrm{Cl}_{2}$, the combined extracts were dried $\left(\mathrm{MgSO}_{4}\right)$ and concentrated. Purification by flash chromatography on silica gel afforded benzoxepin $\mathbf{6 c}$ as a pale yellow oil (20 mg; $0.06 \mathrm{mmol}$; 25\%). $\mathrm{R}_{\mathrm{f}}$ (cyclohexane/EtOAc: 7/3) = 0.40. ${ }^{1} \mathrm{H} \mathrm{NMR}:\left(\mathrm{CDCl}_{3}, 300 \mathrm{MHz}\right): 6.41(\mathrm{~d}, 1 \mathrm{H}, J=8.9 \mathrm{~Hz}), 6.33(\mathrm{~d}, 1 \mathrm{H}, J=8.9 \mathrm{~Hz}), 6.28(\mathrm{~m}$, $3 \mathrm{H}), 6.01(\mathrm{t}, 1 \mathrm{H}, J=5.9 \mathrm{~Hz}), 5.66(\mathrm{~s}, 1 \mathrm{H}), 4.37(\mathrm{t}, 2 \mathrm{H}, J=5.9 \mathrm{~Hz}), 3.74(\mathrm{~s}, 3 \mathrm{H}), 3.61(\mathrm{~s}, 6 \mathrm{H}), 2.42(\mathrm{q}, 2 \mathrm{H}, J=5.9 \mathrm{~Hz}) .{ }^{13} \mathrm{C} \mathrm{NMR}$ (100 MHz, $\mathrm{CDCl}_{3}$ ): 160.5 (2C), 146.7, 145.1, 144.9, 141.0, 137.6, 126.7, 124.8, 121.4, 107.0, 106.4 (2C), 99.5, 76.3, 56.2, 55.4 (2C), 30.6. IR (neat): 3876, 2938, 1590, 1450, 1204, 1153, $1090 \mathrm{~cm}^{-1}$. MS (APCI) $[\mathrm{M}+\mathrm{H}]^{+}=329.6$. Compound 6c, however, does not give completely satisfactory HRMS analyses despite repeated attempts at purification, but all other spectral data were consistent with this structure.

4.19 Synthesis of 9-bromo-8-methoxy-5-(3,4,5-trimethoxyphenyl)-2,3-dihydrobenzo[b]oxepin 6d

To a dioxane ( $3 \mathrm{~mL}$ ) solution of $N$-tosylhydrazone $11 \mathrm{~b}$ (800 mg, $1.84 \mathrm{mmol}), t \mathrm{BuOLi}$ (296 mg; $3.68 \mathrm{mmol}), \mathrm{Pd}_{2} \mathrm{dba}_{3}(168 \mathrm{mg} ; 0.16$ $\mathrm{mmol}$ ), and XPhos (344 mg; $0.72 \mathrm{mmol}$ ) was added 3,4,5-trimethoxyphenyliodide (632 $\mathrm{mg}, 2.16 \mathrm{mmol}$ ). The mixture was stirred at $90{ }^{\circ} \mathrm{C}$ in a sealed tube for $1 \mathrm{~h}$. After cooling at room temperature, the crude mixture was filtered over $\mathrm{SiO}_{2}$ and concentrated. The residue was purified by silica gel chromatography to yield $\mathbf{6 d}$ as brown oil (536 mg; $1.26 \mathrm{mmol} ; 68 \%)$. $\mathrm{R}_{\mathrm{f}}$ (cyclohexane/EtOAc: $\left.8 / 2\right)$ = 0.33. ${ }^{1} \mathrm{H}$ NMR: $\left(\mathrm{CDCl}_{3}, 300 \mathrm{MHz}\right): 6.86(\mathrm{~d}, 1 \mathrm{H}, J=8.7 \mathrm{~Hz}), 6.56(\mathrm{~d}, 1 \mathrm{H}, J=8.7 \mathrm{~Hz}), 6.41(\mathrm{~s}, 2 \mathrm{H}), 6.19(\mathrm{t}, 1 \mathrm{H}, J=6.3 \mathrm{~Hz}), 4.58(\mathrm{t}$, $2 \mathrm{H}, J=6.1 \mathrm{~Hz}), 3.84(\mathrm{~s}, 3 \mathrm{H}), 3.80(\mathrm{~s}, 3 \mathrm{H}), 3.74(\mathrm{~s}, 6 \mathrm{H}), 2.37$ (m, 2H). ${ }^{13} \mathrm{C} \mathrm{NMR}\left(100 \mathrm{MHz}, \mathrm{CDCl}_{3}\right): 156.3,155.1,152.9$ (2C), 141.2 , 138.0, 137.4, 130.0, 127.2, 126.5, 106.7, 106.6, 105.6 (2C), 78.0, 60.9, 56.4, 56.1 (2C). 29.3, IR (neat): 2874, 1985, 1579, 1485, 1445, 1441, 1386, 1333, 1233, 1122, 1004, $975 \mathrm{~cm}^{-1}$. MS (APCI) $[\mathrm{M}+\mathrm{H}]^{+}=421.0\left({ }^{79} \mathrm{Br}\right), 423.5\left({ }^{81} \mathrm{Br}\right) . \mathrm{HRMS}$ calcd for $\mathrm{C}_{20} \mathrm{H}_{22} \mathrm{BrO} 5$ $[\mathrm{M}+\mathrm{H}]^{+} 421.0651$, obsd 421.0663 .

4.20 Synthesis of 8-methoxy-5-(3,4,5-trimethoxyphenyl)-2,3-dihydrobenzo[b]oxepin-9-amine $6 \mathbf{e}$

A solution of $6 \mathbf{d}(100 \mathrm{mg} ; 0.24 \mathrm{mmol}), \mathrm{NaN}_{3}(31 \mathrm{mg} ; 0.48 \mathrm{mmol}), \mathrm{CuI}(3 \mathrm{mg} ; 0.02 \mathrm{mmol})$, DMEDA (0.13 mg; $\left.0.012 \mathrm{mmol}\right)$ and sodium ascorbate $(8 \mathrm{mg} ; 0.04 \mathrm{mmol})$ in a mixture of $\mathrm{DMSO} / \mathrm{H}_{2} \mathrm{O}: 5 / 1(2 \mathrm{~mL})$ was stirred at $60{ }^{\circ} \mathrm{C}$ in a sealed tube. After $12 \mathrm{~h}$, the medium was cooled, quenched with $\mathrm{NH}_{4} \mathrm{Cl}$ and extracted with EtOAc $(3 \times 10 \mathrm{~mL})$. The combined organic layers were dried over $\mathrm{MgSO}_{4}$, filtered and evaporated to dryness. Purification by flash chromatography afforded 6e as a colorless oil (64 mg; $0.18 \mathrm{mmol}$, 75\%). $\mathrm{R}_{\mathrm{f}}($ cyclohexane/EtOAc: $7 / 3)=0.26 .{ }^{1} \mathrm{H} \mathrm{NMR}:\left(\mathrm{CDCl}_{3}, 300 \mathrm{MHz}\right): 6.64-6.43(\mathrm{~m}, 3 \mathrm{H}), 6.37(\mathrm{~d}, 1 \mathrm{H}, J=8.6 \mathrm{~Hz}), 6.17(\mathrm{t}, 1 \mathrm{H}, J$ $=6.0 \mathrm{~Hz}), 4.60-4.45(\mathrm{t}, 2 \mathrm{H}, J=6.0 \mathrm{~Hz}), 3.88(\mathrm{~s}, 6 \mathrm{H}), 3.81(\mathrm{~s}, 6 \mathrm{H}), 2.48(\mathrm{q}, 2 \mathrm{H}, J=6.0 \mathrm{~Hz}) .{ }^{13} \mathrm{C} \mathrm{NMR}\left(100 \mathrm{MHz}, \mathrm{CDCl}_{3}\right): 152.9$ (2C), 147.6, 144.9, 141.9, 138.9, 137.3, 128.1, 125.7, 119.9, 106.0 (2C), 105.5, 76.6, 61.0, 56.2 (2C), 55.8, 30.1, 1C missing. IR (neat): $2444,1985,1579,1485,1415,1333,1233,1122,1004,975 \mathrm{~cm}^{-1}$. MS (APCI) $[\mathrm{M}+\mathrm{H}]^{+}=358.0 . \mathrm{HRMS}$ calcd for $\mathrm{C}_{20} \mathrm{H}_{24} \mathrm{NO}_{5}$ $[\mathrm{M}+\mathrm{H}]^{+} 358.1654$, obsd 358.1665 .

4.21 Synthesis of 8-methoxy-5-(3,4,5-trimethoxyphenyl)-2,3-dihydrobenzo[b]oxepin $\mathbf{6} \mathbf{f}$

A $n \mathrm{BuOH}(2 \mathrm{~mL})$ solution of $6 \mathbf{d}(105 \mathrm{mg} ; 0.24 \mathrm{mmol}), \mathrm{Pd}(\mathrm{OAc})_{2}(1.5 \mathrm{mg} ; 0.0015 \mathrm{mmol}), \mathrm{PPh}_{3}(7.5 \mathrm{mg}$; $0.006 \mathrm{mmol})$, was stirred for $1 \mathrm{~h}$ at $100^{\circ} \mathrm{C}$ in a sealed tube. The medium was cooled, $\mathrm{H}_{2} \mathrm{O}(8 \mathrm{~mL})$ was added to the crude mixture. After extraction with EtOAc $\left(3 \times 5 \mathrm{~mL}\right.$ ), the combined organic layers were dried over $\mathrm{MgSO}_{4}$, filtered and evaporated to dryness. Purification by flash chromatography afforded $\mathbf{6 f}$ as a brown oil $(57 \mathrm{mg} ; 0.165 \mathrm{mmol}, 69 \%)$. $\mathrm{R}_{\mathrm{f}}(\mathrm{cyclohexane} / \mathrm{EtOAc:} 7 / 3)=0.64 .{ }^{1} \mathrm{H} \mathrm{NMR}\left(\mathrm{CDCl}_{3}, 300\right.$ MHz): $6.82(\mathrm{~d}, 1 \mathrm{H}, J=6.9 \mathrm{~Hz}), 6.61(\mathrm{~m}, 1 \mathrm{H}), 6.48(\mathrm{~m}, 1 \mathrm{H}), 6.38(\mathrm{~s}, 2 \mathrm{H}), 6.06(\mathrm{t}, 1 \mathrm{H}, J=6.7 \mathrm{~Hz}), 4.38(\mathrm{t}, 2 \mathrm{H}, J=6.7 \mathrm{~Hz}), 3.81(\mathrm{~s}$, $3 \mathrm{H}), 3.74$ (s, 9H), 2.47 (q, 2H, J=6.7 Hz). ${ }^{13} \mathrm{C} \mathrm{NMR}\left(100 \mathrm{MHz}, \mathrm{CDCl}_{3}\right): 159.8,159.2,152.9$ (2C), 140.9, 139.1, 137.1, 132.2, 126.5, 109.3, 106.7, 105.9 (2C), 76.6, 60.9, 56.1, 55.4 (2C), 30.6, 1C missing. IR (neat): 2937, 1607, 1580, 1499, 1461, 1411, 1356, 1234, 1125, 1007, $826 \mathrm{~cm}^{-1}$. MS (APCI) $[\mathrm{M}+\mathrm{H}]^{+}=343.0$. HRMS calcd for $\mathrm{C}_{20} \mathrm{H}_{23} \mathrm{O}_{5}[\mathrm{M}+\mathrm{H}]^{+} 343.1545$, obsd 343.1552 .

4.22 Synthesis of 4-(8-methoxy-5-(3,4,5-trimethoxyphenyl)-2,3-dihydrobenzo[b] oxepin-9-yl)but-3-yn-1-ol $\mathbf{6 g}$

A DMF (1 mL) solution of $6 \mathbf{d}(80 \mathrm{mg} ; 0.19 \mathrm{mmol})$, but-3-yn-1-ol $(0.17 \mathrm{~mL} ; 0.23 \mathrm{mmol}), \mathrm{PdCl}_{2}\left(\mathrm{PPh}_{3}\right)_{2}(7 \mathrm{mg} ; 0.001 \mathrm{mmol}), \mathrm{PPh}_{3}(7$ $\mathrm{mg} ; 0.03 \mathrm{mmol}), \mathrm{CuI}(2 \mathrm{mg} ; 0.03 \mathrm{mmol})$ and $\mathrm{Et}_{2} \mathrm{NH}(0.4 \mathrm{~mL} ; 0.38 \mathrm{mmol})$ was stirred at $120^{\circ} \mathrm{C}$ under microwave irradiation. After $25 \mathrm{~min}$, the medium was cooled down to room temperature, quenched with $\mathrm{NH}_{4} \mathrm{Cl}$ and extracted with EtOAc $(3 \mathrm{x} 10 \mathrm{~mL})$. The combined organic layers were then dried over $\mathrm{MgSO}_{4}$, filtered and evaporated to dryness. Purification by flash chromatography afforded compounds $\mathbf{6 g}$ as a colorless oil $(59 \mathrm{mg} ; 0.14 \mathrm{mmol} ; 74 \%)$. $\mathrm{R}_{\mathrm{f}}($ cyclohexane/EtOAc: $4 / 6)=0.42 .{ }^{1} \mathrm{H}$ NMR: $\left(\mathrm{CDCl}_{3}, 300\right.$ MHz): $6.90(\mathrm{~d}, 1 \mathrm{H}, J=8.9 \mathrm{~Hz}), 6.57(\mathrm{~d}, 1 \mathrm{H}, J=8.9 \mathrm{~Hz}), 6.46(\mathrm{~s}, 2 \mathrm{H}), 6.20(\mathrm{t}, 1 \mathrm{H}, J=6.0 \mathrm{~Hz}), 4.56(\mathrm{t}, 2 \mathrm{H}, J=6.0 \mathrm{~Hz}), 3.93-3.82(\mathrm{~m}$, $8 \mathrm{H}), 3.80(\mathrm{~s}, 6 \mathrm{H}), 2.80(\mathrm{t}, 2 \mathrm{H}, J=6.0 \mathrm{~Hz}), 2.49(\mathrm{q}, 2 \mathrm{H}, J=6.0 \mathrm{~Hz}) .{ }^{13} \mathrm{C} \mathrm{NMR}\left(100 \mathrm{MHz}, \mathrm{CDCl}_{3}\right): 160.1,159.4,152.9(2 \mathrm{C}), 140.8$, 
138.5, 137.3, 131.2, 126.7, 125.3, 105.7 (2C), 105.3, 94.6, 77.3, 76.0, 60.9 (2C), 56.1 (3C), 29.9, 24.6, 1C missing. IR (neat): 3531, $2939,1582,1504,1486,1463,1412,1356,1333,1283,1236,1126,1102,1055,1007,911,829,731,696 . \mathrm{MS}(\mathrm{APCI})[\mathrm{M}+\mathrm{H}]^{+}=$ 411.0. HRMS calcd for $\mathrm{C}_{24} \mathrm{H}_{27} \mathrm{O}_{6}[\mathrm{M}+\mathrm{H}]^{+} 411.1808$, obsd 411.1808 .

\subsection{Synthesis of 8-methoxy-5-(3,4,5-trimethoxyphenyl)-2,3,4,5-tetrahydrobenzo[b]oxepin-9-ol 25a}

Compound $6 \mathbf{b}(72 \mathrm{mg}, 0.2 \mathrm{mmol})$ in $\mathrm{MeOH}(8 \mathrm{~mL})$ was stirred under a $\mathrm{H}_{2}$ pressure of 20 bars for $1 \mathrm{~h}$ at room temperature. The mixture was then filtered over a pad of Celite and concentrated. Purification by flash chromatography on silica gel afforded $\mathbf{2 5 a}$ as a pale brown oil (46 mg; $0.126 \mathrm{mmol} ; 63 \%)$. $\mathrm{R}_{\mathrm{f}}$ (cyclohexane/EtOAc: $\left.7 / 3\right)=0.30 .{ }^{1} \mathrm{H} \mathrm{NMR}:\left(\mathrm{CDCl}_{3}, 300 \mathrm{MHz}\right): 6.48(\mathrm{~d}, 1 \mathrm{H}, J=6.7$ Hz). 6.40 (s, 2H), 6.21 (d, 1H, J=6.7 Hz), 5.83 (brs, 1H, OH), 4.22-4.10 (m, 2H), 4.02-3.95 (m, 1H), $3.86(\mathrm{~s}, 3 \mathrm{H}), 3.85(\mathrm{~s}, 3 \mathrm{H}), 3.81$ (s, 6H), 2.25-2.10 (m, 2H), 2.05-1.95 (m, 2H). $\left.{ }^{13} \mathrm{C} \mathrm{NMR} \mathrm{(100} \mathrm{MHz,} \mathrm{CDCl}\right)$ : $153.0(2 \mathrm{C}), 146.4,146.1,139.4,137.7,136.2,130.2$, 119.3, 106.6, 105.4 (2), 73.8, 60.9, 56.1 (3C), 48.8, 33.1, 29.7. IR (neat): 3374, 2932, 2160, 1998, 1590, 1462, 1238, 1127, 1085, $1044 \mathrm{~cm}^{-1}$. MS (APCI) $[\mathrm{M}+\mathrm{H}]^{+}=361.0$. Compound 25a, however, does not give completely satisfactory HRMS analyses despite repeated attempts at purification, but all other spectral data were consistent with this structure.

4.24 Synthesis of 4-(8-methoxy-5-(3,4,5-trimethoxyphenyl)-2,3,4,5-tetrahydrobenzo[b]oxepin-9-yl)butan-1-ol 25b

A mixture of $\mathbf{6 g}(90 \mathrm{mg}, 0.21 \mathrm{mmol}), \mathrm{Pd} / \mathrm{C}(9 \mathrm{mg}), \mathrm{MeOH}(30 \mathrm{~mL})$ and 3 drops of AcOH was stirred under a $\mathrm{H}_{2}$ atmosphere for $3 \mathrm{~h}$ at room temperature. The mixture was then filtered over a pad of Celite and concentrated. Purification by flash chromatography on

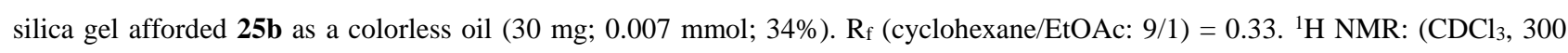
MHz): $6.47(\mathrm{~d}, 1 \mathrm{H}, J=8.5 \mathrm{~Hz}), 6.39(\mathrm{~m}, 3 \mathrm{H}), 4.11(\mathrm{~m}, 2 \mathrm{H}), 3.80-3.75(\mathrm{~m}, 1 \mathrm{H}), 3.78(\mathrm{~s}, 3 \mathrm{H}), 3.74(\mathrm{~s}, 6 \mathrm{H}), 3.70(\mathrm{~s}, 3 \mathrm{H}), 3.62(\mathrm{t}, 2 \mathrm{H}, J$ $=5.8 \mathrm{~Hz}), 2.64(\mathrm{t}, 2 \mathrm{H}, J=6.9 \mathrm{~Hz}), 1.99(\mathrm{~m}, 4 \mathrm{H}), 1.54(\mathrm{~m}, 5 \mathrm{H}) .{ }^{13} \mathrm{C} \mathrm{NMR}\left(100 \mathrm{MHz}, \mathrm{CDCl}_{3}\right): 158.3,157.0,153.2(2 \mathrm{C}), 140.2,136.4$, 130.7, 127.1, 123.6, 105.7 (2C), 105.5, 73.1, 63.1, 61.0, 56.2 (2C), 55.7, 48.6, 33.2, 32.7, 30.1, 26.1,. 23.3. IR (neat): 2938, 1590, $1450,1153,1090 \mathrm{~cm}^{-1}$. MS (APCI) $[\mathrm{M}+\mathrm{H}]^{+}=417.0$. HRMS calcd for $\mathrm{C}_{24} \mathrm{H}_{33} \mathrm{O}_{6}[\mathrm{M}+\mathrm{H}]^{+}$417.2277, obsd 417.2288.

\subsection{Cell Culture and Proliferation Assay}

Cancer cell lines were obtained from the American type Culture Collection (Rockville, MD) and were cultured according to the supplier's instructions. Briefly MDA-MB231 and H1299 cells were grown in Dulbecco minimal essential medium (DMEM) containing $4.5 \mathrm{~g} / \mathrm{L}$ glucose supplemented with $10 \%$ FCS and 1\% glutamine. Human K562 leukemia and HCT116 colorectal carcinoma cells were grown in RPMI 1640 containing 10\% FCS and $1 \%$ glutamine. Cell lines were maintained at $37{ }^{\circ} \mathrm{C}$ in a humidified atmosphere containing $5 \% \mathrm{CO}_{2}$. Cell viability was assessed using Promega CellTiter-Blue TM reagent according to the manufacturer's instructions. Cells were seeded in 96-well plates $(5 \times 103$ cells/well) containing $50 \mu \mathrm{L}$ growth medium. After $24 \mathrm{~h}$ of culture, the cells were supplemented with $50 \mu \mathrm{L}$ of the tested compound dissolved in DMSO (less than $0.1 \%$ in each preparation). After $72 \mathrm{~h}$ of incubation, $20 \mu \mathrm{L}$ of resazurin was added for $2 \mathrm{~h}$ before recording fluorescence $(\lambda \mathrm{ex}=560 \mathrm{~nm}, \lambda \mathrm{em}=590 \mathrm{~nm}) \mathrm{using}$ a Victor microtiter plate fluorimeter (Perkin-Elmer, USA). The GI 50 corresponds to the concentration of the tested compound that caused a decrease of $50 \%$ in fluorescence of drug treated cells compared with untreated cells. Experiments were performed in triplicate. The GI50 values for all compounds were compared to the GI50 of CA-4 and isoCA-4 and were measured the same day under the same conditions.

\subsection{Tubulin Binding Assay}

Sheep brain tubulin was purified according to the method of Shelanski[71]by two cycles of assembly-disassembly and then dissolved in the assembly buffer containing 0.1 M MES, $0.5 \mathrm{mM} \mathrm{MgCl}_{2}, 1 \mathrm{mM}$ EGTA, and $1 \mathrm{mM} \mathrm{GTP}$, pH 6.6 (the concentration of tubulin was about $2-3 \mathrm{mg} / \mathrm{mL}$ ). Tubulin assembly was monitored by fluorescence according to reported procedure[72] using DAPI as fluorescent molecule. Assays were realized on 96-well plates prepared with Biomek NKMC and Biomek 3000 from Beckman Coulter and read at $37^{\circ} \mathrm{C}$ on Wallac Victor fluorimeter from Perkin Elmer. The $\mathrm{IC}_{50}$ value of each compound was determined as the concentration which decreased the maximum assembly rate of tubulin by $50 \%$ compared to the rate in the absence of compound. The $\mathrm{IC}_{50}$ values for all compounds were compared to the $\mathrm{IC}_{50}$ of isoCA-4 and measured the same day under the same conditions.

4.27 Cell Cycle Analysis 
Exponentially growing cancer cells (K562, H1299, HCT116, MDA-MB231) were incubated with benzoxepine $6 \mathbf{b}$ at a concentration of $5 \mathrm{nM}$ or DMSO for $24 \mathrm{~h}$. Cell-cycle profiles were determined by flow cytometry on a FC500 flow cytometer (Beckman-Coulter, France) as described previously.[73]

\subsection{Apoptosis Assay}

Apoptosis was measured by the Apo-one homogeneous caspase-3/7 assay (Promega Co, WI) according to the manufacturer's recommendations. Briefly, HCT116 and H1299 cells were subcultured on a 96-well plate with $5 \times 10^{4}$ cells/well in $100 \mu \mathrm{L}$ medium. After $24 \mathrm{~h}$ of incubation, the medium in the 96-well plate was discarded and replaced with medium containing different concentrations of benzoxepin $6 \mathbf{b}(1,5$, and $10 \mathrm{nM})$ or $0.1 \%$ DMSO (as negative control). The treated cells were incubated for $24 \mathrm{~h}$, each well then received $100 \mu \mathrm{L}$ of a mixture of caspase substrate and Apo-one caspase 3/7 buffer. After $1 \mathrm{~h}$ of incubation, the fluorescence of sample was measured using a Victor microtiter plate fluorimeter (Perkin-Elmer, USA) at $527 \mathrm{~nm}$.

\subsection{Molecular modeling}

For ligand preparation, compound $\mathbf{6 b}$ was built using Chemdraw and converted to 3D using the dbtranslate program from Unity module of Sybyl (Tripos International, S.L., Missouri, USA). The 3D structure was minimized and a conformational analysis was performed (systematic search) selecting all possible rotatable bonds. The most stable structure of each compound was selected and used for docking. For the receptor preparation, the x-ray structure of tubulin-colchicine complex (PDB: 1sa0) was used for this study downloaded from the Protein Data Bank. Hydrogen atoms were added and an energy minimisation using AMBER 8.0[74] was performed keeping the $\alpha$-carbons constrained by a constraint-force of $50 \mathrm{kcal} / \mathrm{mol} \AA^{2}$, which permitted to side-chains free to move and kept the same secondary structures. Over the refined model we defined the active site of tubulin as $12 \AA$ around the crystallized colchicine. We performed a docking of all compounds using the program GOLD 4.1.2.[75]

\section{Acknowledgments}

The CNRS (Centre National de la Recherche Scientifique) is gratefully acknowledged for financial support of this research. We thank the MRES (Ministère de la Recherche et de l'Enseignement Supérieur) for a financial fellowship to E.R. Our laboratory BioCIS-UMR 8076 is a member of the Laboratory of Excellence LERMIT supported by a grant from ANR (Agence Nationale de la Recherche, ANR-10-LABX-33). The work on tubulin was supported by a grant from ANR (ANR-09-BLAN-0071).

\section{References}

[1] G. R. Pettit, S. B. Singh, E. Hamel, C. M. Lin, D. S. Alberts, D. Garcia-Kendall, Experientia 45 (1989) 209-211.

[2] G. R. Pettit, M. R. Rhodes, D. L. Herald, E. Hamel, J. M. Schmidt, R. K. Pettit, J. Med. Chem. 48 (2005) 4087-4099.

[3] A. T. Mc Gown, B. W. Fox, Cancer Chemother. Pharmacol. 26 (1990) 79-81.

[4] G. R. Pettit, B. Toki, D. L. Herald, P. Verdier-Pinard, M. R. Boyd, E. Hamel, R. K. Pettit, J. Med. Chem. 41 (1998) 1688-1695.

[5] D. J. Chaplin, G. R. Pettit, S. A. Hill, Anticancer Res. 19 (1999) 189-195.

[6] D. J. Chaplin, S. A. Hill, Int. J. Radiat. Oncol. Biol. Phys. 54 (2002) 1491-1496

[7] G. R. Pettit, C. Temple, V. L. Narayanan, R. Varma, M. R. Boyd, G. A. Rener, N. Bansal, Anti-Cancer Drug Des. 10 (1995) $299-309$.

[8] G. J. Rustin, S. M. Galbraith, H. Anderson, M. Stratford, L. K. Folkes, L. Sena, L. Gumbrell, P. M. Price, J. Clin. Oncol. 21 (2003) $2815-2822$.

[9] A. Dowlati, K. Robertson, M. Cooney, W. P. Petros, M. Stratford, J. Jesberger, N. Rafie, B. Overmoyer, V. Makkar, B. Stambler, A. Taylor, J. Waas, J. S. Lewin, K. R. McCrae, S. C. Remick, Cancer Res. 62 (2002) 3408-3416.

[10] G. R. Pettit, M. R. Rhodes, D. L. Herald, D. J. Chaplin, M. R. L. Stratford, E. Hamel, R. K. Pettit, J.-C. Chapuis, D. Oliva, Anti-Cancer Drug Des. 13 (1998) 981-993.

[11] K. Ohsumi, T. Hatanaka, K. Fujita, R. Nakagawa, Y. Fukuda, Y. Nihei, Y. Suga, Y. Morinaga, Y. Akiyama, T. Tsuji, Bioorg. Med. Chem. Lett. 8 (1998) 3153-3158.

[12] S. Aprile, E. Del Grosso, G. C. Tron, G. Grosa, Drug Metab. Dispos. 35 (2007) 2252-2261.

[13] B. L. Flynn, G. S. Gill, D.W. Grobelny, J. H. Chaplin, D. Paul, A. F. Leske, T. C. Lavranos, D. K. Chalmers, S. A. Charman, E. Kostewicz, D. M. Shackleford, J. Morizzi, E. Hamel, M. K. Jung, G. Kremmidiotis, J. Med. Chem. 54 (2011) 6014-6027.

[14] N. H. Nam, Curr. Med. Chem. 10 (2003) 1692-1722 and references therein.

[15] G. C. Tron, T. Pirali, G. Sorba, F. Pagliai, S. Busacca, A. A. Genazzani, J. Med. Chem. 49 (2006) 3033-3044 and references therein.

[16] M. Marelli, F. Conforti, G. A. Statti, X. Cachet, S. Michel, F. Tillequin, F. Menichini, Curr. Med. Chem. 18 (2011) 3035-3081 and references therein.

[17] A. Chaudhary, S. N. Pandeya, P. Kumar, P. P. Sharma, S. Gupta, N. Soni, K. K. Verma, G. Bhardwaj, Mini-Rev. Med. Chem. 7 (2007) $1186-$ 1205 and references therein.

[18] A. Cirla, J. Mann Nat. Prod. Rep. 20 (2003), 558-564 and references therein

[19] M. Arthuis, R. Pontikis, G. G. Chabot, J. Seguin, L. Quentin, S. Bourg, L. Morin-Allory, J.-C. Florent ChemMedChem 6 (2011) 1693-1705 and references therein.

[20] Y. Shan, J. Zhang, Z. Liu, M. Wang, Y. Dong, Curr. Med. Chem. 18 (2011) 523-538 and references therein.

[21] O. Provot, A. Giraud, J.-F. Peyrat, M. Alami, J.-D. Brion, Tetrahedron Lett. 46 (2005) 8547-8550. 
[22] C. Mousset, A. Giraud, O. Provot, A. Hamze, J. Bignon, J. M. Liu, S. Thoret, J. Dubois, J.-D. Brion, M. Alami, Bioorg. Med. Chem. Lett. 18 (2008) 3266-3271.

[23] S. Messaoudi, A. Hamze, O. Provot, B. Tréguier, J. Rodrigo De Losada, J. Bignon, J. M. Liu, J. Wdzieczak-Bakala, S. Thoret, J. Dubois, J.-D. Brion, M. Alami, ChemMedChem 6 (2011) 488-497.

[24] C. Mousset, O. Provot, A. Hamze, J. Bignon, J.-D. Brion, M. Alami, Tetrahedron 64 (2008) 4287-4294.

[25] N. L'Hermite, A. Giraud, O. Provot, J.-F. Peyrat, M. Alami, J.-D. Brion, Tetrahedron 62 (2006) 1199- $\square 12002$.

[26] E. Rasolofonjatovo, O. Provot, A. Hamze, J. Bignon, S. Thoret, J.-D. Brion, M. Alami, Eur. J. Med. Chem. 45 (2010) $3617-3626$.

[27] A. Hamze, D. Veau, O. Provot, J.-D. Brion, M. Alami, J. Org. Chem. 74 (2009) 1337-1340.

[28] F. Liron, M. Gervais, J.-F. Peyrat, M. Alami, J.-D. Brion, Tetrahedron Lett. 44 (2003) 2789-2794.

[29] B. Tréguier, A. Hamze, O. Provot, J.-D. Brion, M. Alami, Tetrahedron Lett. 50 (2009) 6549-6552.

[30] S. Messaoudi, B. Tréguier, A. Hamze, O. Provot, J.-F. Peyrat, J. Rodrigo De Losada, J. M. Liu, J. Bignon, J. Wdzieczak-Bakala, S. Thoret, J. Dubois, J.-D. Brion, M. Alami, J. Med. Chem. 52 (2009) 4538-4542.

[31] A. Hamze, A. Giraud, S. Messaoudi, O. Provot, J.-F. Peyrat, J. Bignon, J. M. Liu, J. Wdzieczak-Bakala, S. Thoret, J. Dubois, J.-D. Brion, M. Alami, ChemMedChem 4 (2009) 1912-1924.

[32] A. Hamze, E. Rasolofonjatovo, O. Provot, C. Mousset, D. Veau, J. Rodrigo, J. Bignon, J. M. Liu, J. Wdzieczak-Bakala, S. Thoret, J. Dubois, J.D. Brion, M. Alami, ChemMedChem 6 (2011) 2179-2191.

[33] M. A. Soussi, S. Aprile, S. Messaoudi, O. Provot, E. Del Grosso, J. Bignon, J. Dubois, J.-D. Brion, G. Grosa, M. Alami, ChemMedChem 6 (2011) 1781-1788.

[34] K. G. Pinney, V. P. Mocharla, Z. Chen, C. M. Garner, A. Ghatak, M. Hadimani, J. Kessler, J. M. Dorsey, K. Edvardsen, D. J. Chaplin, J. Prezioso, U. R. Ghatak, U.S. Patent Appl. Publ. (2004) 20040043969 A1.

[35] K. G. Pinney, V. P. Mocharla, P. Vani, Z. Chen, C. M. Garner, A. Ghatak, M. Hadimani, J. Kessler, J. M. Dorsey PCT Int. Appl. (2001), WO 2001068654 A2 20010920.

[36] E. Rasolofonjatovo, O. Provot, A. Hamze, J. Rodrigo, J. Bignon, J. Wdzieczak-Bakala, D. Desravines, J. Dubois, J.-D. Brion, M. Alami, Eur. J. Med. Chem. 52 (2012) 22-32.

[37] E. Rasolofonjatovo, B. Tréguier, O. Provot, A. Hamze, E. Morvan, J.-D. Brion, M. Alami, Tetrahedron Lett. 52 (2011) 1036-1040.

[38] E. Rasolofonjatovo, B. Tréguier, O. Provot, A. Hamze, J.-D. Brion, M. Alami, Eur. J. Org. Chem. (2012) $1603-1615$.

[39] M. Sriram, J. J. Hall, N. C. Grohmann, T. E. Strecker, T. Wootton, A. Franken, M. L. Trawick, K. G. Pinney, Bioorg. Med. Chem. 16 (2008) 8161-8171.

[40] K. G. Pinney, M. Sriram, U.S. PCT Appl. WO (2006), 2006138427 A2.

[41] J. Barluenga, P. Moriel, C. Valdés, F. Aznar, Angew. Chem. Int. Ed. 46 (2007) 5587-5590.

[42] J. Barluenga, C, Valdés, Angew. Chem. Int. Ed. 50 (2011) 7486-7500.

[43] M. Alami, F. Liron, M. Gervais, J.-F. Peyrat, J.-D. Brion, Angew. Chem., Int. Ed. 41 (2002), 1578-1580.

[44] A. Hamze, D. Veau, O. Provot, J.-D. Brion, M. Alami, J. Org. Chem. 74 (2009), 1337-1340.

[45] G. S. Gill, D. W. Grobelny, J. H. Chaplin, B. L. Flynn, J. Org. Chem. 73 (2008) 1131-1134.

[46] K. Sonogashira, Y. Tohda, N. Hagihara, Tetrahedron Lett. 16 (1975) 4467-4470.

[47] M. Alami, F. Ferri, G. Linstrumelle, Tetrahedron Lett. 34 (1993) 6403-6406.

[48] N. Olivi, E. Thomas, J.-F. Peyrat, M. Alami, J.-D. Brion, Synlett (2004) 2175-2179.

[49] G. Le Bras, O. Provot, J.-F. Peyrat, M. Alami, J.-D. Brion, Tetrahedron Lett. 47 (2006) 5497-5501.

[50] M. Jacubert, O. Provot, J.-F. Peyrat, A. Hamze, J.-D. Brion, M. Alami, Tetrahedron 66 (2010) 3775-3787.

[51] M. Jacubert, A. Hamze, O. Provot, J.-F. Peyrat, J.-D. Brion, M. Alami, Tetrahedron Lett. 50 (2009) 3588-3592.

[52] G. Le Bras, A. Hamze, S. Messaoudi, O. Provot, P.-B. Le Calvez, J.-D. Brion, M. Alami, Synthesis (2008) $1607 \square 1611$.

[53] E. Brachet, A. Hamze, J.-F. Peyrat, J.-D. Brion, M. Alami, Org. Lett. 12 (2010) 4042-4045.

[54] For the synthesis of 5-arylbenzoxepins according to Suzuki couplings, see ref 44 and I. Barrett, M. J. Meegan, R. B. Hughes, M. Carr, A. J. S. Knox, N. Artemenko, G. Golfis, D. M. Zisterer, D. G. Lloyd, Bioorg. Med. Chem. 16 (2008) 9554-9573.

[55] I. Barrett, M. Carr, N. O’Boyle, L. M. Greene, A. J. S. Knox, D. G. Lloyd, D. M. Zisterer, M. J. Meegan, J. Enzym. Inhib. Med. Chem. 25 (2010) $180-194$

[56] M. Jacubert, A. Tikad, O. Provot, A. Hamze, J.-D. Brion, M. Alami, Eur. J. Org. Chem. (2010), 4492-4500.

[57] A. Bekaert, O. Provot, O. Rasolojaona, M. Alami, J.-D. Brion, Tetrahedron Lett. 46 (2005) 4187-4191.

[58] M. Jacubert, A. Tikad, O. Provot, A. Hamze, J.-D. Brion, M. Alami, Eur. J. Org. Chem. 2010, 4492-4500.

[59] During the preparation of this manuscript, a similar strategy for the synthesis of benzosuberene derivatives was reported, see: Z. Chen, C. J. O’Donnell, A. Maderna, Tetrahedron Lett. 53 (2012) 64-66.

[60] S. Messaoudi, J.-D. Brion, M. Alami, Adv. Synth. Catal. 352 (2010) 1677-1687.

[61] S. Messaoudi, J.-D. Brion, M. Alami, Mini-Rev. Org. Chem. 8 (2011) 448-454.

[62] J. Chen, Y. Zhang, L. Yang, X. Zhang, J. Liu, L. Li, H. Zhang, Tetrahedron 63 (2007) 4266-4270.

[63] K. Anderson, T. Ikawa, R. E. Tundel, S. L. Buchwald, J. Am. Chem. Soc. 128 (2006) 10694-10695.

[64] A. Giraud, O. Provot, A. Hamze, J.D. Brion, M. Alami, Tetrahedron Lett., 49 (2008) 1107-1110.

[65] K. Ohsumi, R. Nakagawa, Y. Fukuda, T. Hatanaka, Y. Morinaga, Y. Nihei, K. Ohishi, Y. Suga, Y. Akiyama, T. Tsuji, J. Med. Chem. 41 (1998) 3022-3032.

[66] M. Cushman, D. Nagarathnam, D. Gopal, H.-M. He, C. M. Lin, E. Hamel, J. Med. Chem. 35 (1992) $2293-2314$.

[67] Y. G. Tong, X. W. Zhang, M. Y. Geng, J. M. Yue, X. L. Xin, T. Fang, S. Xu, L. J. Tong, M. H. Li, C. Zhang, W. H. Li, L. P. Lin, J. Ding, Mol. Pharmacol. 69 (2006) 1226-1233.

[68] R. B. Ravelli, B. Gigant, P. A. Curmi, I. Jourdain, S. Lachkar, A. Sobel, M. Knossow, Nature 428 (2004) 198-202.

[69] M. Rosillo, G. Dominguez, L. Casarrubios, U. Amador, J. Pérez-Castells, J. Org. Chem. 69 (2004), $2084-2093$.

[70] A.R. Pereira, W.K. Strangman, F. Marion, L. Feldberg, D. Roll, R. Mallon, I. Hollander, R.J. Anderson, J. Med. Chem. 53 (2010) $8523-8533$.

[71] M. L. Shelanski, F. Gaskin, C. R. Cantor, Proc. Natl. Acad. Sci. U.S.A. 70 (1973) 765-768.

[72] D. M. Barron, S. K. Chatterjee, R. Ravindra, R. Roof, E. Baloglu, D. G. I. Kingston, S. Bane, Anal. Biochem. 315 (2003) $49-56$.

[73] C. Venot, M. Maratrat, C. Dureuil, E. Conseiller, L. Bracco, L. Debussche, EMBO J. 17 (1998) 4668-4679.

[74] D. A. Case, T. A. Darden, T. E. Cheatham, III, C. L. Simmerling, J. Wang, R. E. Duke, R. Luo, K. M. Merz, B. Wang, D. A. Pearlman, M. Crowley, S. Brozell, V. Tsui, H. Gohlke, J. Mongan, V. Hornak, G. Cui, P. Beroza, C. Schafmeister, J. W. Caldwell, W. S. Ross, P. A. Kollman, AMBER8: University of California, San Francisco, (2008).

[75] M. L. Verdonk, J. C. Cole, M. J. Hartshorn, C. W. Murray, R. D. Taylor, Proteins 52 (2003) 609-623. 
[1] K. Ohsumi, R. Nakagawa, Y. Fukuda, T. Hatanaka, Y. Morinaga, Y. Nihei, K. Ohishi, Y. Suga, Y. Akiyama, T. Tsuji, J. Med. Chem. 41 (1998) 3022-3032. 


\section{Legends to Figures, Schemes and Tables}

Figure 1. Representative inhibitors of tubulin polymerization and rational drug design from CA-4 and isoCA-4 to dihydrobenzoxepin analogues 6.

Figure 2. Retrosynthesis of 5-arylbenzoxepins 6.

Scheme 1. Synthesis of vinylstannane 9a and vinyliodide 10a. Reagent and conditions: a) $\mathrm{PdCl}_{2}\left(\mathrm{PPh}_{3}\right)_{2}\left(2 \mathrm{~mol}_{2}\right), \mathrm{Bu}_{3} \mathrm{SnH}(1.2$ equiv), THF, $20^{\circ} \mathrm{C}$; b) $\mathrm{I}_{2}, \mathrm{CH}_{2} \mathrm{Cl}_{2}, 20^{\circ} \mathrm{C}$.

Scheme 2. Synthesis of dihydrobenzoxepins 6b,c. Reagent and conditions: a) $\mathrm{MOMCl}$ (2 equiv), $i \mathrm{Pr}_{2} \mathrm{NH}$ (2 equiv), $\mathrm{CH}_{2} \mathrm{Cl}_{2}$; b) $\mathrm{But}-$ 3-yn-1-ol (1.1 equiv), $\mathrm{PdCl}_{2}\left(\mathrm{PPh}_{3}\right)_{2}(8 \mathrm{~mol} \%), \mathrm{CuI}(15 \mathrm{~mol} \%), \mathrm{Et}_{3} \mathrm{~N}$; c) PTSA (1 equiv), $\mathrm{H}_{2} \mathrm{O}, 100{ }^{\circ} \mathrm{C}$, sealed tube; d) DEAD (1.5 equiv), $\mathrm{PPh}_{3}$ (1.5 equiv), THF; e) $\mathrm{TsNHNH}_{2}$ (2.5 equiv), PTSA (20 mol\%), EtOH reflux; f) $\mathrm{Pd}_{2} \mathrm{dba}_{3}(10 \mathrm{~mol} \%), \mathrm{XPhos}(20 \mathrm{~mol} \%)$, $t \mathrm{BuOLi}$ (2 equiv), ArI (1 equiv), $90{ }^{\circ} \mathrm{C}$, sealed tube; g) $\mathrm{AlCl}_{3}$ (5 equiv), $\mathrm{CH}_{2} \mathrm{Cl}_{2}$.

Scheme 3. Synthesis of dihydrobenzoxepins $\mathbf{6 b}, \mathbf{6 d - g}$ and tetrahydrobenzoxepins 25a,b. Reagent and conditions: a) (i) $\mathrm{Hg}(\mathrm{OAc})_{2}(1$ equiv), $\mathrm{NaBr}$ (1 equiv), $50{ }^{\circ} \mathrm{C}, \mathrm{EtOH}$; (ii) $\mathrm{MPHT}$ (1 equiv), $\mathrm{CH}_{3} \mathrm{CN}$; b) 3-bromoprop-1-ene (1.2 equiv), $\mathrm{K}_{2} \mathrm{CO}_{3}\left(1.2\right.$ equiv), $\mathrm{CH}_{3} \mathrm{CN}$; c) vinylmagnesium chloride (1.2 equiv), THF; d) Grubbs II catalyst, $5 \mathrm{~mol} \%, \mathrm{CH}_{2} \mathrm{Cl}_{2}, 20{ }^{\circ} \mathrm{C}$; e) $\mathrm{H}_{2}, \mathrm{Pd} / \mathrm{C}, \mathrm{MeOH}, \mathrm{AcOH}$ cat.; f) $\mathrm{PCC}, \mathrm{CH}_{2} \mathrm{Cl}_{2} ; \mathrm{g}$ ) $\mathrm{TsNHNH}_{2}$ (1 equiv), PTSA (10 mol\%), $\mathrm{MgSO}_{4}$ (1 equiv), EtOH, reflux; h) $\mathrm{Pd}_{2} \mathrm{dba}_{3}$ (10 mol\%), XPhos (40 mol\%), $t \operatorname{BuOLi}\left(2\right.$ equiv), 3,4,5-trimethoxyiodobenzene (1.2 equiv), $90{ }^{\circ} \mathrm{C}$, sealed tube; i) $\mathrm{Pd}_{2} \mathrm{dba}_{3}(5 \mathrm{~mol} \%), t \mathrm{BuXPhos}(15 \mathrm{~mol} \%), \mathrm{KOH}(3$ equiv), dioxane- $\mathrm{H}_{2} \mathrm{O}, 90{ }^{\circ} \mathrm{C}$, sealed tube; j) $\mathrm{CuI}(10 \mathrm{~mol} \%)$, TMEDA (6 mol\%), $\mathrm{NaN}_{3}$ (2 equiv), potassium ascorbate (6 mol\%) DMSO- $\mathrm{H}_{2} \mathrm{O}, 90{ }^{\circ} \mathrm{C}$, sealed tube; k) $\mathrm{Pd}(\mathrm{OAc})_{2}(1 \mathrm{~mol} \%), \mathrm{PPh}_{3}(2.5 \mathrm{~mol} \%), n \mathrm{BuOH}, 100{ }^{\circ} \mathrm{C}$, sealed tube; 1$) n \mathrm{But}-3$-yn-1-ol (1.2 equiv), $\mathrm{PdCl}_{2}\left(\mathrm{PPh}_{3}\right)_{2}(5 \mathrm{~mol} \%), \mathrm{PPh}_{3}(15 \mathrm{~mol} \%), \mathrm{CuI}(15 \mathrm{~mol} \%), \mathrm{Et}_{2} \mathrm{NH}$ (2 equiv), DMF, $120{ }^{\circ} \mathrm{C}, \mathrm{MWI}$.

Table 1. Cytotoxic activity of dihydrobenzoxepins $\mathbf{6 b - g}$ and tetrahydrobenzoxepins 25a,b against HCT116 ${ }^{\text {a }}$

Table 2. Cytotoxic activity and inhibition of tubulin polymerization of selected compounds

Figure 3. Effects of benzoxepin $\mathbf{6 b}$ at a concentration of $5.0 \mathrm{nM}$ on cell cycle distribution in various cancer cell lines.

Figure 4. Apoptotic effects of $\mathbf{6 b}$ in HCT116 and H1299 cells. The results are expressed in the percentage of apoptotic cells detected following $24 \mathrm{~h}$ of treatment with $\mathbf{6} \mathbf{b}$ at different concentrations.

Figure 5. Docked pose of $\mathbf{6 b}$ (gray) overlayed with isoCA-4 (blue) in the tubulin binding site. 


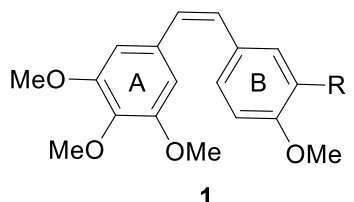

CA-4

1a $\mathrm{R}=\mathrm{OH}$

CA-4P 1b $\mathrm{R}=\mathrm{OPO}_{3} \mathrm{Na}_{2}$

$\mathrm{NH}_{2} \mathrm{CA}-4$ 1c $\mathrm{R}=\mathrm{NH}_{2}$

FCA-4 1d $R=F$

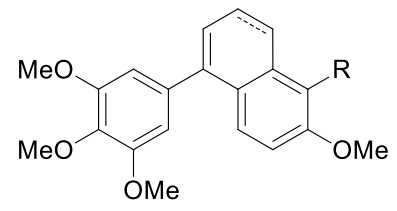

(Dihydro)naphtalenes 3<smiles>[X]c1c(OC)ccc2c1CCCC=C2c1cc(OC)c(OC)c(OC)c1</smiles>

Benzosuberenes 5

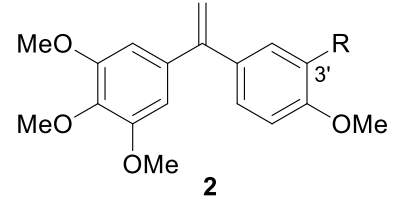

isoCA-4 2a $\quad \mathrm{R}=\mathrm{OH}$

iso $\mathrm{NH}_{2} \mathrm{CA}-4 \quad 2 \mathrm{~b} \quad \mathrm{R}=\mathrm{NH}_{2}$

isoFCA-4 2c $\quad \mathrm{R}=\mathrm{F}$

2d $\mathrm{R}=\mathrm{C} \equiv \mathrm{C}-\mathrm{CH}_{2} \mathrm{OH}$

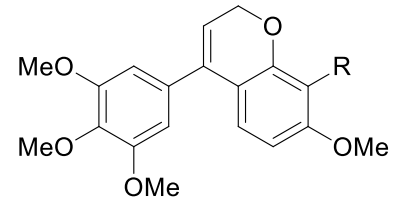

Chromenes $4^{[17]}$

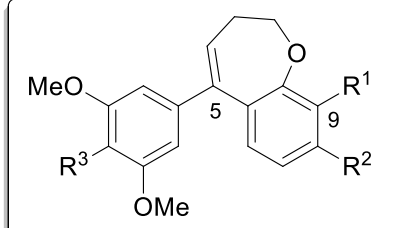

Dihydrobenzo[b]oxepins 6

$<$ Figure 1 $>$ 


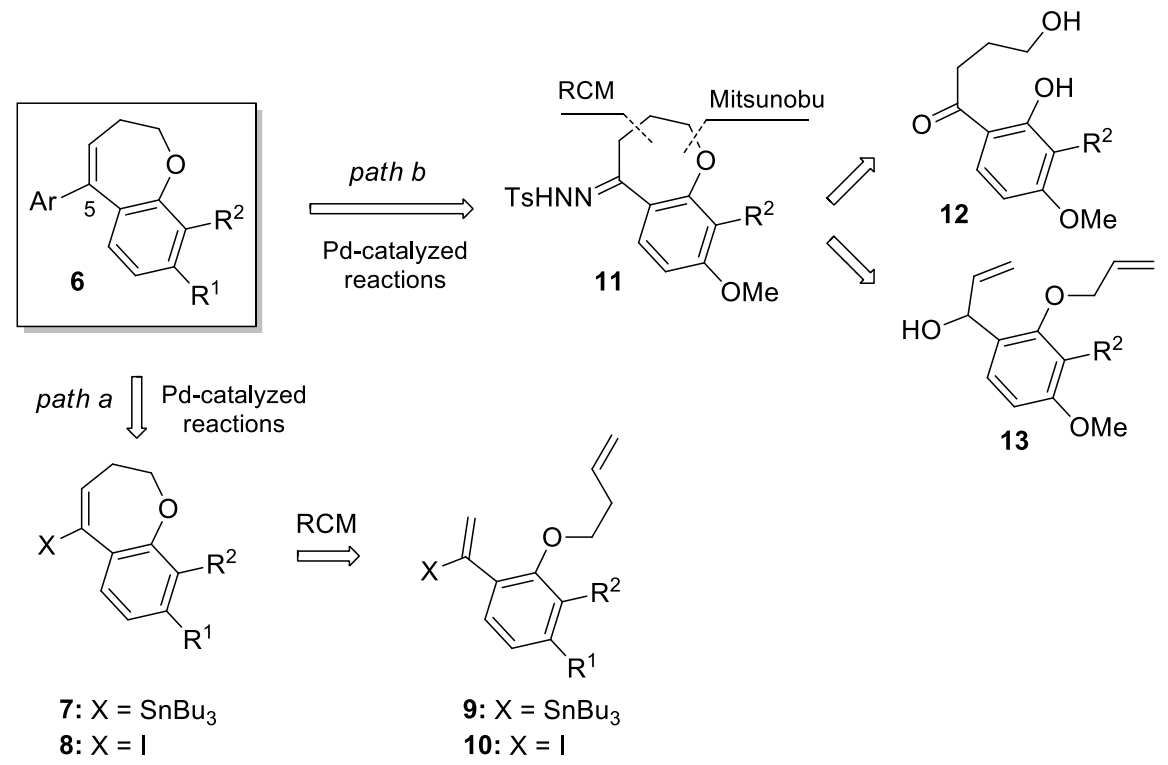

<Figure 2> 

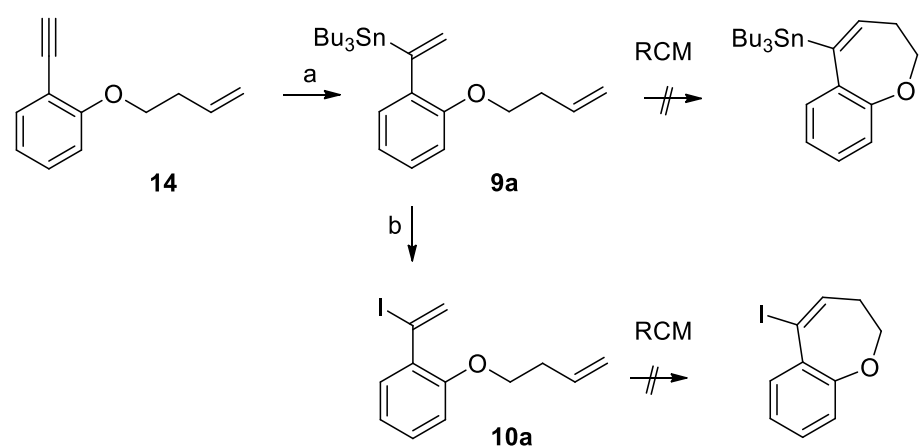

<Scheme 1> 

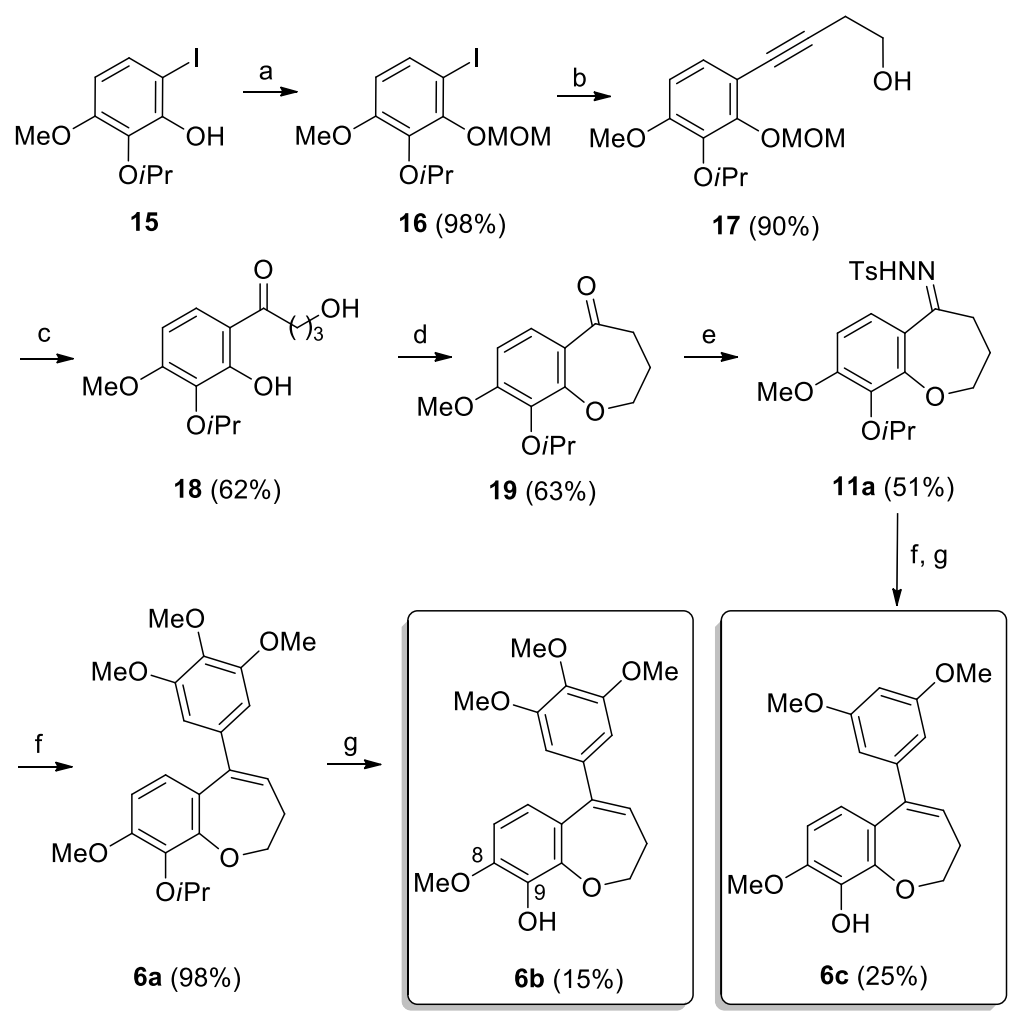

<Scheme 2> 

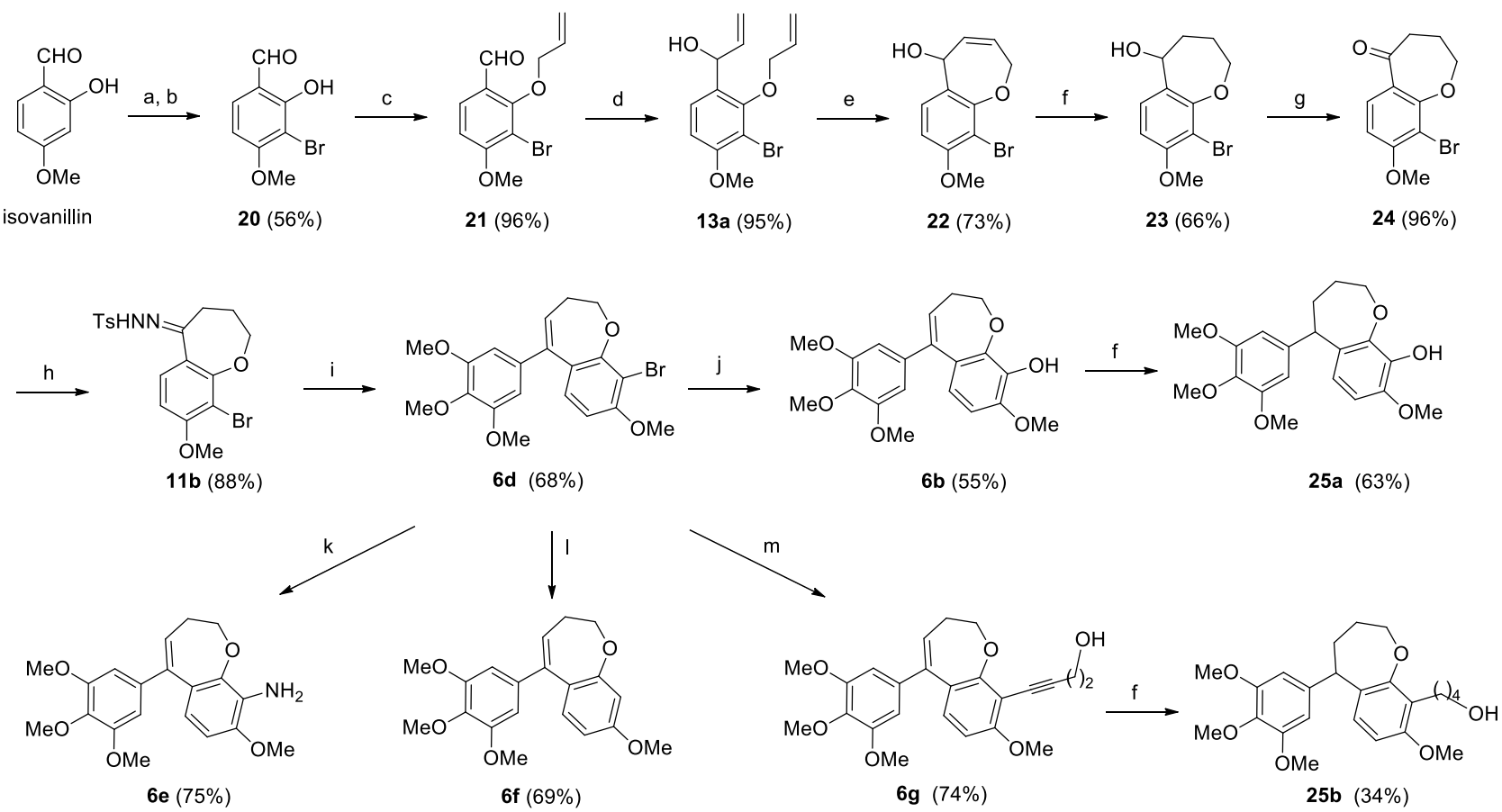

<Scheme 3> 


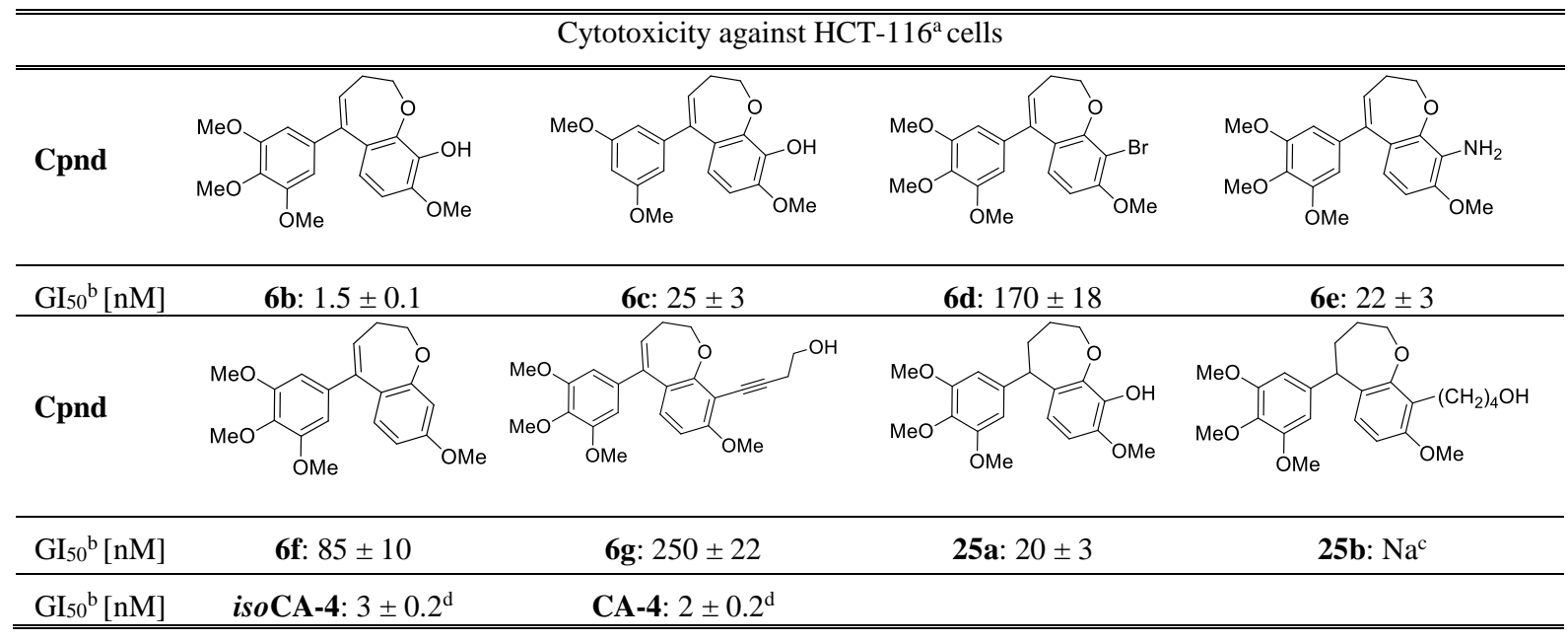

${ }^{a}$ HCT-116 Human colon carcinoma. ${ }^{\mathrm{b}} \mathrm{GI}_{50}$ is the concentration of compound needed to reduce cell growth by $50 \%$ following $72 \mathrm{~h}$ cell treatment with the tested drug (average of three experiments). ${ }^{\mathrm{c}}$ Non active. ${ }^{\mathrm{d}}$ The GI50 values for CA-4, isoCA-4 were determined in this study.

<Table 1> 


\begin{tabular}{|c|c|c|c|c|c|}
\hline \multirow{2}{*}{ Cpnd } & \multicolumn{4}{|c|}{ Cytotoxicity $\mathrm{GI}_{50}{ }^{\mathrm{a}}[\mathrm{nM}]$} & \multirow{2}{*}{$\begin{array}{l}\text { Inhibition of } \\
\text { tubulin } \\
\text { polymerization } \\
\mathrm{IC}_{50}{ }^{\mathrm{c}}[\mu \mathrm{M}]\end{array}$} \\
\hline & $\mathrm{HCT} 116^{\mathrm{b}}$ & $\mathrm{K} 562^{\mathrm{b}}$ & H1299b & MDA-MB231 & \\
\hline $6 \mathbf{b}$ & $1.5 \pm 0.1$ & $8 \pm 1$ & $4.5 \pm 0.3$ & $3 \pm 0.2$ & $3.8 \pm 0.4$ \\
\hline $6 c$ & $25 \pm 3$ & $30 \pm 4$ & $32 \pm 3$ & $28 \pm 4$ & $3.2 \pm 0.3$ \\
\hline $6 e$ & $22 \pm 3$ & $40 \pm 4$ & $30 \pm 2$ & $8 \pm 1$ & $3.6 \pm 0.4$ \\
\hline 6f & $85 \pm 10$ & $100 \pm 9$ & $180 \pm 15$ & $250 \pm 23$ & $3.9 \pm 0.4$ \\
\hline $25 \mathbf{a}$ & $20 \pm 3$ & $50 \pm 5$ & $7 \pm 1$ & $15 \pm 2$ & $3.3 \pm 0.3$ \\
\hline$i s o \mathrm{CA}-4^{\mathrm{d}}$ & $3 \pm 0.2$ & $5 \pm 0.3$ & $3 \pm 0.2$ & $4 \pm 0.3$ & $1.5 \pm 0.2$ \\
\hline
\end{tabular}

${ }^{\mathrm{a}} \mathrm{GI}_{50}$ is the concentration of compound needed to reduce cell growth by $50 \%$ following $72 \mathrm{~h}$ cell treatment with the tested drug (average of three experiments). 'HCT116, colon carcinoma; K562, myelogenous leukaemia; H1299, non-small cell lung carcinoma; MDA-MB231 hormone-independent breast cancer. 'ITP, Inhibition of Tubulin Polymerization; IC50 is the concentration of compound required to inhibit $50 \%$ of the rate of microtubule assembly (average of three experiments). ${ }^{\mathrm{d}}$ The $\mathrm{GI}_{50}$ and $\mathrm{IC}_{50}$ values (cytotoxicity and ITP, respectively) for isoCA-4 were determined in this study.

<Table 2> 


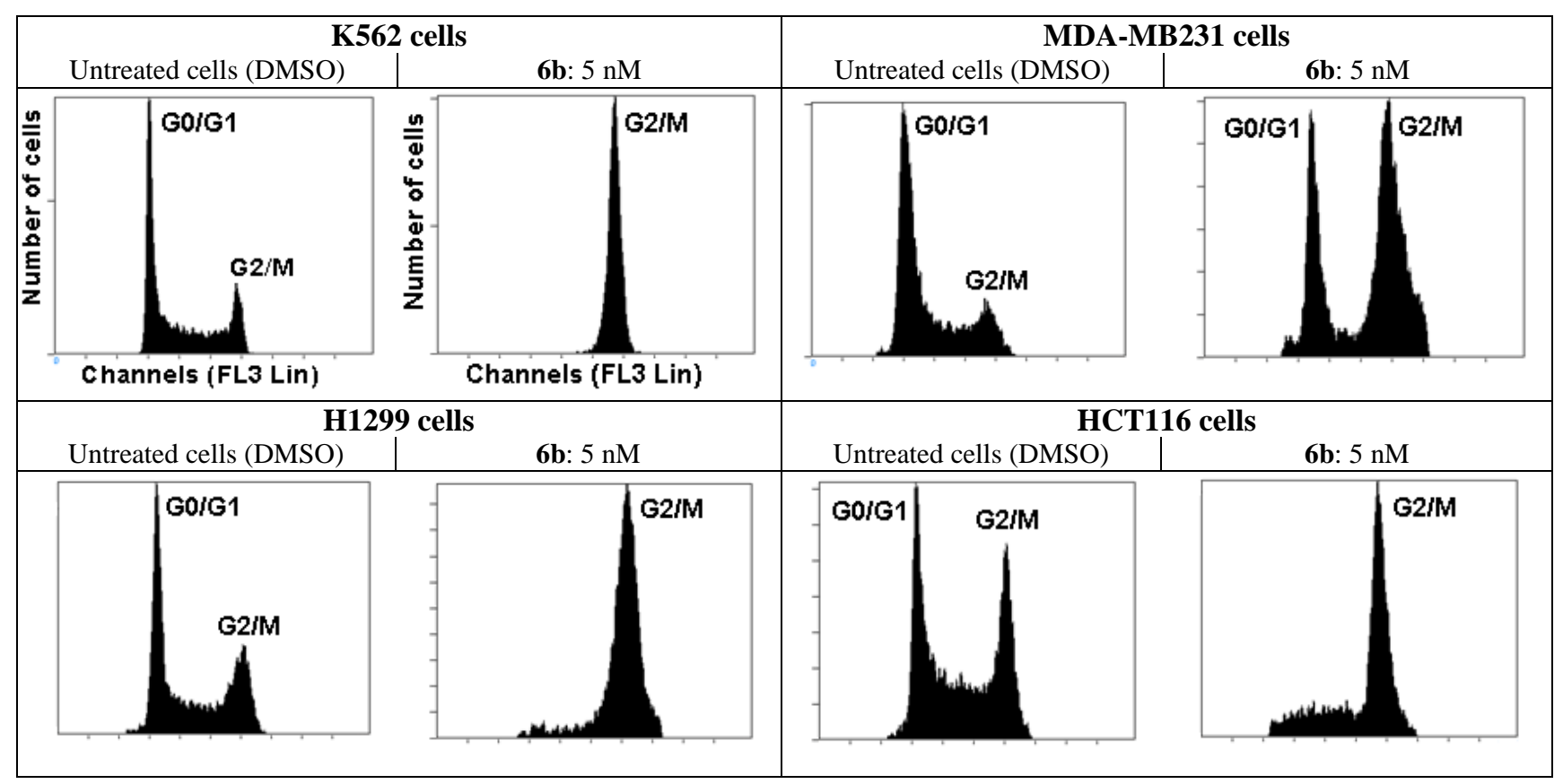

<Figure 3> 


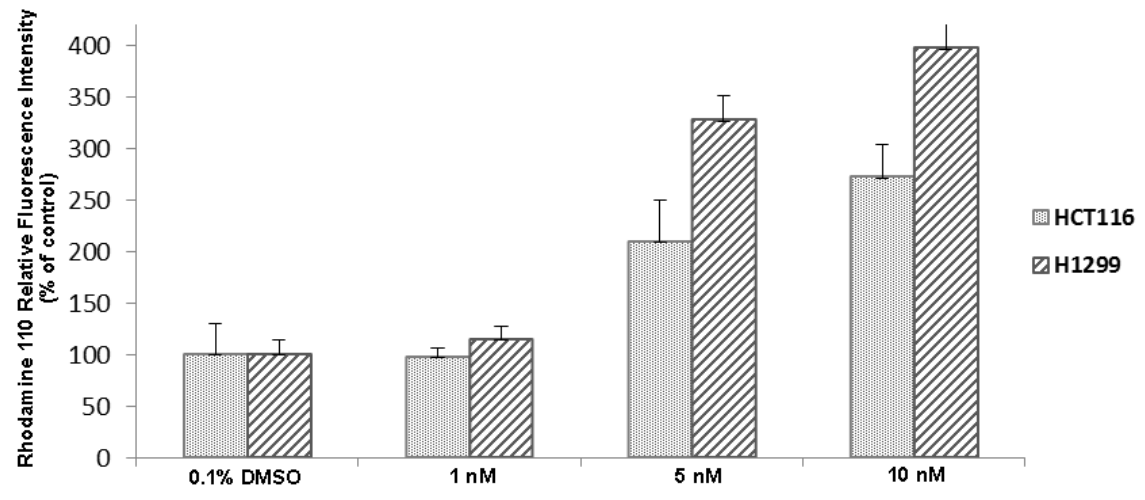

<Figure 4> 


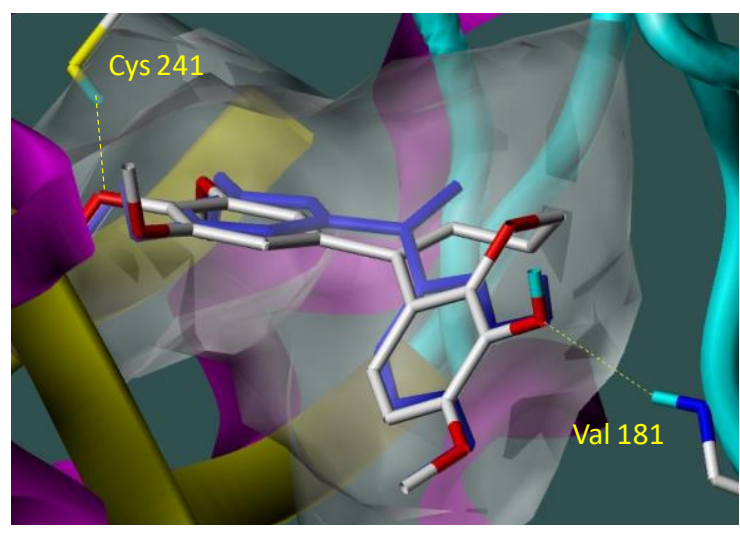

<Figure 5> 